\title{
HERMANN HELLER MARCHA AL EXILIO (UN ENSAYO DE TEORÍA DEL PENSAMIENTO POLÍTICO Y CONSTITUCIONAL)
}

JAVIER RUIPÉREZ 


\section{SUMARIO}

1.- SENTIDO Y SIGNIFICADO DE ESTE ESCRITO. EL HOMENAJE COMO ACTO DE JUSTICIA Y DE REPARACIÓN MORAL A MANUEL GARCÍA-PELAYO. 2.- MARZO DE 1933, UNA FECHA CLAVE EN LA VIDA DE HERMANN HELLER: LA MARCHA AL EXILIO. 3.- CONSIDERACIONES TEÓRICO-IDEOLÓGICAS OBJETIVAS QUE JUSTIFICABAN LA DECISIÓN HELLERIANA DE NO RETORNAR A ALEMANIA: 3.1.- La derogación fáctica del Texto Constitucional como motivo objetivo y general para ponerse a salvo del totalitarismo nazi; 3.2.- La Ley de plenos poderes y su significado como justificación de la marcha al exilio. 4.- SU PREVISIBLE SITUACIÓN PERSONAL EN LA DICTADURA COMO CAUSA DEL EXILIO: HELLER COMO «ENEMIGO TOTAL»: 4.- Su inevitable condición de «enemigo personal» del régimen, o de los orígenes biológicos como causa de persecución; 4.2.- Heller como «enemigo académico»; 4.3.- La ideología democrático-socialista como fundamento de su condición de «enemigo político». 5.- CONSIDERACIONES FINALES 
Fecha recepción:

Fecha aceptación:

\title{
HERMANN HELLER MARCHA AL EXILIO (UN ENSAYO DE TEORÍA DEL PENSAMIENTO POLÍTICO Y CONSTITUCIONAL)
}

\author{
POR \\ JAVIER RUIPÉREZ \\ Catedrático de Derecho Constitucional \\ Universidad de Coruña
}

\begin{abstract}
"En la medida en que los acontecimientos de los últimos meses o semanas han transformado las convicciones de algunos miembros de la Facultad, ruego a estos últimos que no tengan en cuenta algunas de mis palabras de despedida. Por el contrario le ruego tenga la bondad de transmitir mi saludo y mi agradecimiento afectuoso a todos aquellos colegas que, a pesar de los acontecimientos arriba referidos, han conservado de mi un buen recuerdo. Dada mi fe en el Espiritu, [...], tengo la certeza de que permaneceré ligado a ellos en el futuro, incluso si las circunstancias externas nos impidieran reunirnos"
\end{abstract}

(H. Heller, Madrid, 5 de octubre de 1934)

1. SENTIDO Y SIGNIFICADO DE ESTE ESCRITO. EL HOMENAJE COMO ACTO DE JUSTICIA Y DE REPARACIÓN MORAL A MANUEL GARCÍA-PELAYO

Es para mí un honor, a la par que un cierto motivo de satisfacción, el ser requerido por los Drs. Torres del Moral y Tajadura Tejada para que contribuya a 
este número monográfico de la Revista de Derecho Político, con el que se quiere rendir homenaje al primer Presidente del actual Tribunal Constitucional español. En realidad, he de aclarar que ha sido, justamente, su finalidad la que me ha llevado inmediatamente a aceptar su amable invitación. Y es que, como, en 2002 y en México D.F., tuve ocasión de manifestarle a su mujer, Graciela Soriano de García-Pelayo, considero que festejar a tan insigne iuspublicista constituye un deber inexcusable para todo los españoles, académicos o no. Se trata, en efecto, de realizar un acto, que no sólo, y de manera indiscutible, es de justicia, sino también debido, de reconocimiento intelectual a quien, sin disputa, ha sido uno de los más grandes, -y de los pocos que, dadas las singulares circunstancias por las que atravesó el intento de formular una dogmática del Derecho Público en la España de los siglos XIX y XX (P. De Vega), en realidad merecen esa consideración-, constitucionalistas españoles, que, por ello mismo, se ha convertido, de uno u otro modo, en un auténtico referente para quienes nos dedicamos al estudio del Estado, el Derecho y la Política. Pero, al mismo tiempo, y con el mismo acierto, y sobre todo en el marco de la llamada recuperación de la memoria histórica, la iniciativa de la dirección del la Revista de Derecho Político nos permite llevar a cabo un acto de reparación, siquiera sea moral, para D. Manuel, quien, como "perdedor" de la contienda bélica, fue una víctima de una absurda, cruel y sanguinaria dictadura. Me explico.

De todos es, sin duda, harto conocida la obra de García-Pelayo. Constituiría, de esta suerte, una absoluta impertinencia por mi parte el que procediera aquí a realizar una valoración — que, de cualquier forma, y como no podría ser de otro modo, es altamente positiva - sobre la misma y los méritos que en ella concurren. De igual manera, resultaría también improcedente el que me detuviese a llevar a cabo una, más o menos amplia, disertación que, tomando en consideración los méritos del homenajeado, tuviese por objeto elogiar lo oportuno y pertinente de la iniciativa de los Profesores Torres y Tajadura, así como justificar mi participación en ella. El reconocimiento prácticamente unánime, si no unánime, del magisterio de García-Pelayo por parte de los constitucionalistas españoles e iberoamericanos, hace, como es obvio, innecesaria cualquier observación al respecto, la cual, me imagino, no haría más que repetir lo que en otras muchas contribuciones de este volumen va a decirse, y por personas, que aunque sólo sea por haberle conocido y tratado personalmente, mucho más autorizadas que yo.

Sí quisiera, no obstante, hacer una precisión sobre este asunto. En este sentido, diré que, bajo la inspiración de Tierno Galván, tengo para mí que uno de los mayores méritos de García-Pelayo reside en la metodología que empleó en sus estudios de Derecho Constitucional. Éste, a mi juicio, se deriva del hecho de que, de un modo que resulta difícilmente cuestionable, asumió el Profesor za- 
morano las enseñanzas de Smend, - cuya influencia queda patente con la publicación, en 1948, de su célebre "Constitución y Derecho Constitucional (Evolución y crisis del ambos conceptos)» —, y de Heller. De ahí que, nadie puede negarlo, adoptase una posición crítica hacia las construcciones del positivismo jurídico, tanto en su inicial expresión formalista como en la jurisprudencial.

De una forma mucho más concreta, me refiero a que existe en García-Pelayo una plena y total aceptación de los planteamientos de Heller en relación con esa disciplina académica, que aparece, en 1928, en la Alemania del período entre guerras y que recibe, indistintamente, el nombre de Teoría del Estado o Teoría de la Constitución. Desde luego, y en primer lugar, esto parece evidente en relación con la comprensión de Heller sobre el cómo ha de llevarse a cabo el estudio del Derecho. Comprensión que, de manera tan patente como contundente, quedaba resumida en la afirmación del alemán de que «Todo problema jurídico, sin excepción, tiene sus raíces, de un lado, en la sociología y del otro, mirando hacia arriba, en la esfera de lo ético-político. Por tanto, los problemas jurídicos no solamente pueden ser estudiados desde los puntos de vista causal y normativo, sino que, además, exigen se efectúe ese doble estudio». La consecuencia que el propio Heller extraerá de esta afirmación, no puede ser, en verdad, más clara y, al mismo tiempo, más acertada. Y ésta no es otra que la de que, como escribió en 1929, «El imperialismo de un único método se revela estéril en todas las ciencias del espíritu», entre las que, como ciencia social-normativa que es, se encuentra el Derecho Constitucional. Ninguna dificultad habrá, entiendo, en que todos convengamos en que a esta máxima se atuvo siempre García-Pelayo.

La coincidencia no acaba aquí. Así, en segundo término, es, para nosotros, también evidente que, partiendo de lo anterior, García-Pelayo admitirá como correcta la idea que el insigne Profesor socialdemócrata alemán tenía sobre la función que había de cumplir la Teoría del Estado y de la Constitución: la explicación, en términos jurídico-públicos, y siempre crítica aunque sin llegar a poner en cuestión el principio de legitimidad que actúa como criterio vertebrador y justificador del sistema, de las relaciones de poder que se verifican en una Comunidad Política concreta, y en un momento histórico determinado, tratando, a través de la búsqueda en lo devenido de lo que está por devenir y mediante su actividad valorativa creadora del sistema, de influir en su evolución futura. Para que el constitucionalista, como jurista, pueda ser capaz de ofrecer una cabal y ponderada explicación de una realidad jurídica y política que él no crea, pero que, inevitablemente, le condiciona, ha de trabajar, y aquí enlaza inmediatamente con lo que acabamos de ver, con una Teoría del Estado y de la Constitu- 
ción que ha de ser formulada desde una posición intermedia, equidistante y, en definitiva, superadora de las que hasta ese momento habían representado las concepciones extremas en la dogmática alemana del Derecho, la Política y el Estado. Concepciones extremas que, en 1926, Heller va, de algún modo, a identificar con el absoluto politicismo e historicismo de Schmidt, y con el total juridicismo de Rehm.

La concepción que mantiene Heller sobre la Teoría del Estado y de la Constitución aparece, en tales circunstancias, de forma meridiana. En efecto, para él, si bien es verdad que, porque el Código Constitucional no tiene otro objeto que la regulación de la vida del Estado y, en consecuencia, la ordenación del proceso político democrático, al constitucionalista le cumple la tarea de tratar de explicar las relaciones de poder en la Comunidad Política, no es menos cierto que, en tanto en cuanto es una auténtica norma jurídica, el estudio de la Constitución no puede, como tratando de superar un formalismo que disuelve el Estado en relaciones lógico-jurídicas, hacía Schmidt —a quien, sin embargo, Heller reconoce el mérito de haber comprendido que el jurista precisa contar con el conocimiento, y comprensión, de todos los datos jurídicos, metajurídicos y extrajurídicos que explican el porqué de los preceptos jurídicos vigentes—, quedar reducido al instinto político, que, a la postre, lleva a la construcción de una Teoría del Estado que oscila entre consideraciones de carácter histórico, sociológico y ético-metafísico, prescindiendo de todo lo jurídico. Pero sucede también que siendo el Código Jurídico-Político Fundamental una norma jurídica, ésta, por su objeto de regulación mismo, tiene un contenido político del que su estudioso nunca puede prescindir. Lo que, en último extremo, significa que tampoco resulta correcto proceder, como, siguiendo la senda marcada por Stahl — fundador, junto con Hegel, del monarquismo alemán moderno, $\mathrm{y}$, sin duda alguna, el iniciador de la concepción positivista de la Teoría del Estado-, había pretendido hacer Rehm, a la formulación de un Derecho Constitucional ajeno a toda sensibilidad política, y que encontraría su máxima expresión en el intento de Kelsen de, bajo la influencia de Cohen, reducir toda la problemática de la Constitución a reglas lógico-matemáticas y geométricas. Teoría del Estado, Ciencia Política, Sociología, Filosofía del Estado, Teoría Política e Historia no son, ni pueden ser, desde esta perspectiva, materias radical y definitivamente ajenas al jurista, y, en particular, al constitucionalista. Por el contrario, éste necesita su conocimiento y, de un modo u otro, su práctica para ejercer adecuadamente su misión.

Que García-Pelayo participaba de esta visión del Derecho Constitucional, que, además, aprendió directamente de Heller, es algo que, para nosotros, resulta evidente. Sólo así se entiende la amplitud de los temas tratados por quien hoy homenajeamos, y la riqueza conceptual con la que abordó su estudio. En efecto, 
Teoría del Estado, Ciencia Política, Sociología, Teoría Política e Historia se darían cita a lo largo de toda su obra como jurista.

De cualquier forma, ocurre que si la categoría y grandeza intelectual y académica de García-Pelayo son de todos conocidas y, amén de justificar sobradamente este acto de homenaje, todos, en mayor o menor medida, nos dedicamos a ponérselo de manifiesto a los estudiantes de nuestras Facultades, lo que acaso, y en nombre de «lo políticamente correcto», no reciba la suficiente atención, y lo que en pocas ocasiones se les cuenta los estudiantes españoles del siglo XXI, es su condición de represaliado político, excluido y marginado y, en definitiva, y de un modo muy similar al de Tierno Galván, de vencido. Desde luego, durante la dictadura. Pero también lo sería, de algún modo, en sus últimos años de vida.

Es esta circunstancia la que explica, y justifica de manera definitiva, el que resulte especialmente oportuna hoy, cuando se ha publicado una Ley de la Memoria Histórica, la iniciativa de Torres y Tajadura de lanzar este número monográfico. Pero es también esta circunstancia la que obliga a entender la misma no como un mero homenaje a quien fue uno de nuestros más válidos y brillantes constitucionalistas, sino como un auténtico acto de reparación moral hacia su figura como hombre de bien. Y de ahí, su innegable justicia.

Entender esto último, no ha de resultar muy difícil de lograr. Para ello, basta con tomar en consideración el momento histórico que le tocó vivir, y el modo en que quienes detentaban el poder político se lo hicieron vivir. Si se hace esto, no habrá impedimento alguno para que todos podamos convenir en que en la persona de García-Pelayo se hicieron singularmente reales aquellas palabras que Azaña escribió en el exilio sobre la dictadura. Lo son, en efecto, las remitidas por éste a Blanco Amor: «La situación de España no tiene remedio. Allí no queda nada: ni Estado, ni riqueza, ni comercio, ni industria, ni hábitos de trabajo, ni posibilidad de encontrarlo, ni respeto que no sea impuesto por el terror. [...]. Difícil es reconstruir el Estado y la organización económica, pero mucho más difícil es rehacer las condiciones mínimas para la convivencia social. [...]. Han hecho pedazos lo que nadie es capaz de recomponer». Pero lo son también las que el político alcalaíno escribió a Carlos Esplá: en la España franquista, "Además de las crueldades, la estupidez pura».

Lo anterior es especial, y, de manera innegable, sangrantemente cierto en relación con la situación de García-Pelayo. Siendo éste uno de nuestros más brillantes iuspublicistas, se le impidió el acceso a la Cátedra de Derecho Político. La causa real —aunque, dada la naturaleza del régimen, no pudiera ser expresada explícitamente- de esta ignominia, era que desde el aparato gubernamental de la dictadura franquista García-Pelayo era considerado como un enemigo total del nacional-catolicismo. Poco importaba el hecho de que se trataba de una dicta- 
dura surgida de una guerra civil en la que, por decirlo con Azaña, «La sinrazón de los enemigos [de la República] proviene del hecho de la sublevación contra el régimen basado en el sufragio, y se confirma por el hecho de gobernar a España tiránicamente», y que, porque "Aunque hubiesen sido ciertos todos los males que se achacaban a la República y aunque hubiese sido una realidad la amenaza comunista, la prevención y el remedio no podían consistir en un alzamiento y en una guerra atroces», jamás podría gozar de legitimidad. Como en estos casos suele suceder, la culpa se le imputa al otro; al que se mantuvo fiel a los principios y valores de la Democracia.

Si éste era el crimen, los cargos existentes contra García-Pelayo no eran, quién podría hoy negarlo, más dignos de mejor causa. Ciertamente, los mismos no podían hacerse públicos ni en el momento de decidirse que no se le permitiría acceder al cuerpo de funcionarios docentes universitarios del Estado, ni cuando el franquismo, llevado a ello por la situación internacional, hubo de aceptar plenamente las formas de los totalitarismos fascistas del período entre guerras y, en consecuencia, se vio obligado a tratar de convencer a la sociedad internacional y a sus súbditos en el interior, -y a alguno bien que le convenció-, de dos cosas. A saber: $1 .^{\text {a) }}$ que el régimen nacido del golpe de julio de 1936 no sólo era un régimen democrático, sino que, repitiendo lo que, como puso de relieve Heller, se había convertido en una auténtica obsesión de los totalitarismos fascistas, se trataba del mejor de todos ellos, y, en realidad, del único viable. 2. ${ }^{\text {a) }} \mathrm{Y}$ con la misma apelación que Mussolini y Hitler habían hecho a las construcciones del positivismo jurídico formalista - que encontraba, sin duda alguna, su expresión más radical en aquel Hans Kelsen que, por un lado, llevaba hasta el último extremo la despersonalización del poder, incluido el democrático, y, por otro, afirmaba que el Rechtsstaat es posible « independientemente del contenido ético, político y social del que se le dote» —, el cual, habiendo vaciado a esta forma política de todo su contenido material, lo dejaba reducido a un Estado jurídico regido por una vacía nomocracia en la que lo único importante son las formas, también el franquismo proclamaría, sin recato alguno, que España constituía un auténtico Estado de Derecho.

En este contexto, obvio es que la dictadura no podía hacer públicos los cargos contra García-Pelayo. La razón de ello no es difícil de comprender. Y ha sido el Profesor De Vega quien, con la brillantez, rigor y contundencia que le caracterizan, lo puso, si bien actuando desde el cripticismo, la simulación y el doble lenguaje que las circunstancias históricas le imponían, claramente de manifiesto. $\mathrm{Al}$ ser la dictadura franquista un régimen totalitario que, como tal, se fundamentaba en una visión unitaria y exclusivista del mundo desde la que las categorías de división, fraccionamiento o y discrepancia no existen, se convertía en 
doctrina oficial del nacional-catolicismo, como lo había sido en el absolutismo monárquico y en el resto de los totalitarismos modernos, la idea de que no es posible un orden político en el que no se dé un acuerdo en lo fundamental, lo que, indudablemente, se veía potenciado por su apelación al nacionalismo como autentica ideología de la ocultación. De ahí que, como de un modo bien distinto al que se corresponde con la Democracia, el franquismo pretendiera presentarse como el reino de la unanimidad.

Admitir que a García-Pelayo, como discrepante, se le castigaba, hubiera sido, desde la óptica franquista, tanto como reconocer la existencia de un conflicto. Y esto era incompatible con la propia naturaleza totalitaria del régimen dictatorial de la monarquía católica española. Al igual que en otros muchos supuestos, el problema planteado por García-Pelayo sería resuelto por el Gobierno franquista de la misma manera en que siempre lo han hecho los regímenes totalitarios. Esto es $-\mathrm{y}$ como, con total acierto y precisión, han indicado, p. ej., un Dahrendorf o Friedrich—, lo que, al no poder admitir oficialmente la existencia de un conflicto, se hacía era negarlo. Bien entendido que, como en su día puso de manifiesto De Vega, la negación del conflicto en modo alguno significaba la renuncia a ejercer sobre el discrepante, y en cuanto que expresaba la ausencia de la unanimidad exigida por el detentador del poder, la más enérgica de las represiones. Para ello, no dudaron los franquistas, como tampoco antes habían dudado Mussolini y Hitler, en aplicar la lógica inherente de la concepción totalitaria de la política que, con una innegable influencia soreliana, y de un modo bien brillante, aunque con una más que notable falta de rigor científico (Heller), Schmitt había concretado en la contraposición «amigo-enemigo».

Esto fue lo que sucedió con nuestro homenajeado: condenado sin formulación oficial de cargos, García-Pelayo, un vencido, vio cómo se le impedía fácticamente su acceso a la Cátedra de Derecho Político. Pero los cargos existían. Y los pusieron de manifiesto aquellos Catedráticos de Derecho Político adscritos al régimen que protestaban, y trataban de que se impidiese su toma de posesión, por el hecho de que, en 1948, se hubiera permitido que Tierno, no sin dificultades: singularmente la de su condición de rojo oficial y agnóstico, hubiera ganado, en concurso-oposición nacional, la Cátedra de Derecho Político de la Universidad de Murcia. Básicamente, éstos se reducían a que García-Pelayo era militante del Partido Socialista desde 1932, y que, además, ha permanecido fiel a, por decirlo con palabras de Antonio Machado, «nuestra República, la cien veces legítima república de todos los españoles».

Ante tamaña injusticia, García-Pelayo, el vencido, tomará la decisión de trasladarse a Venezuela. De esta suerte, el exilio interior que había conocido desde el 
fin de la injustificada, e injustificable, contienda civil, se transformaba en exilio exterior. Desde allí, D. Manuel extendería su noble magisterio por toda la Comunidad Iberoamérica. También entre los intelectuales españoles del exilio, los transterrados, y los que permanecían en lo que se dio en llamar la España peninsular, o territorial.

No es menester que nos entretengamos aquí a poner de manifiesto la importancia, y la grandeza intelectual, de la obra desarrollada por García-Pelayo. Lo que es evidente, y está general, si no unánimemente, admitido, no precisa de justificación. Y caer en este vicio no sería más que un, ciertamente impertinente, inútil y lamentable, ejercicio de solemnización de lo obvio.

Lo que nos interesa es recordar que, una vez muerto el general/dictador ferrolano, e iniciado el tránsito a la democracia, se llevaron a cabo unos, muy loables y justos, intentos de rehabilitación de la figura de nuestro homenajeado. Permítaseme que, de entre todos ellos, destaque aquí los que, por mi propia filiación académica, mejor conozco: los protagonizados por el Grupo Tierno-Ollero. Ahí está, por ejemplo, la propuesta que, en el Curso académico 1978-1979, realizó mi dilecto Maestro para que García-Pelayo fuese investido Doctor Honoris Causa por el Singular Studio Salmanticensis, donde entonces el Profesor De Vega era el titular de la Cátedra de Derecho Político.

Estas iniciativas rehabilitadoras tuvieron una muy desigual suerte. Ésta fue, de alguna manera, escasa en el ámbito de lo académico. Y no porque la que, por ejemplo, presentó Pedro De Vega no fuese aceptada. Lo fue, y sin mucha resistencia, aunque hubieron de transcurrir varios años hasta que se representó el acto formal de tal investidura. Sin embargo, el éxito le fue únicamente relativo. La razón de que haya de ser considerado así, es la de que esta iniciativa, como otras similares que protagonizaron otros miembros del escalafón, se enmarcaba en una operación mucho más amplia. De lo que se trataba era que de igual modo que se había hecho ya con otros ilustres vencidos, como, por ejemplo, el procesalista $\mathrm{Al}$ calá-Zamora, el químico orgánico Giral, el constitucionalista Tierno, etc., a quienes se les había reintegrado en sus respectivas Cátedras, nuestro hoy conmemorado fuese reparado al ser reconocido como Catedrático de la Universidad española, cuando entre nosotros se iniciaba una nueva andadura democrática. Es, precisamente, en esta segunda dimensión donde, como decimos, todas estas bienintencionadas iniciativas se vieron frustradas.

Lo anterior se hace especialmente patente si, como, por lo demás, es siempre necesario hacer, todas estas circunstancias a las que nos referimos se enmarcan en su contexto espacio-temporal. Desde esta perspectiva, es menester recordar que todos estos intentos de que García-Pelayo fuese rehabilitado y reparado en el ámbito de lo académico tenían lugar en los albores de la actual etapa democrática es- 
pañola. Momento éste en que desde el aparato gubernamental se ponía en marcha la figura de los "Catedráticos extraordinarios», y se otorgaron estas Cátedras atendiendo a los méritos de sus titulares. No seré yo el que venga a discutir la idoneidad de todos los que accedieron al cuerpo de funcionarios docentes universitarios del Estado como Catedráticos extraordinarios. Su nombramiento estaba justificado por su currículum, y en algunos supuestos, como en el caso de Tuñón de Lara, aquél venía a corregir lo que, con Azaña, hemos llamado la «estupidez pura» de la dictadura. Lo que me parece lamentable es que siendo, como eran, incontestables e incuestionables los de Manuel García-Pelayo, sus méritos académicos no fueran juzgados suficientes para obtener una de esas Cátedras extraordinarias, y que, de este modo, pudiera haber sido acreedor de una pensión del Estado en su jubilación.

La conclusión, en tales circunstancias, es evidente, y es sólo una. Pese a los esfuerzos de muchos de sus colegas, García-Pelayo continuaba siendo un vencido en relación con la que debía haber sido su Universidad.

Mayor fortuna hubo, o, al menos, así lo parecía, en el ámbito de la política práctica. En efecto, García-Pelayo fue nombrado Magistrado del Tribunal Constitucional. Y no sólo esto. D. Manuel fue elegido como Presidente de aquel órgano. Su primer Presidente.

Hubiera podido pensarse que con este doble nombramiento había culminado ese proceso de reconciliación entre la España republicana y la España de la monarquía católica, que venía propugnando la oposición democrática al franquismo y que, con el acceso de Suárez al Gobierno, asumía el stablishment. Parecería, en efecto, que los españoles habíamos entrado por fin en razón, y que, en consecuencia, estábamos prestos a hacer reales como mínimo dos de aquellas grandes ideas que Azaña tuvo como medios para superar el conflicto una vez que la contienda bélica acabase. Nos referimos, en primer lugar, a las palabras que el Presidente pronunció el 18 de julio de 1938: «Pero es obligación moral, [...], cuando se acabe [la guerra ...], sacar la lección y de la musa del escarmiento el mayor bien posible, y cuando la antorcha pase a otras manos, a otros hombres, a otras generaciones, que se acordarán, si alguna vez sienten que les hierve la sangre iracunda y otra vez el genio español vuelve a enfurecerse con la intolerancia y con el odio y con el espíritu de destrucción, que piensen en los muertos y que escuchen su lección: la de esos hombres, que [...] ya no tienen odio, ya no tienen rencor, y nos envían, [...], el mensaje de la patria eterna que dice a todos sus hijos: Paz, Piedad y Perdón». En segundo término, a aquellas otras que el ya ex Presidente de la República dirigió a Carlos Esplá: «Los que piensen en cooperar el día de mañana al restablecimiento de la vida civil en España, habrán de remontar mucho más atrás que el régimen de partidos vigente en la República, 
más atrás que las jerárquicas conocidas, más atrás que la legalidad destruida, para llegar a la fuente de donde brotó todo esto».

Vana ilusión era ésta. Bastó con que García-Pelayo hiciese uso del voto de calidad que, como Presidente del Tribunal Constitucional, le correspondía y que, como consecuencia de ello, el custodio de la Constitución declarase la constitucionalidad de la expropiación del holding RUMASA, para comprobar lo lejos que estaban de haberse realmente materializado los sabios consejos de Azaña. Lo habían intentado, en efecto, las fuerzas que integraron la oposición democrática al franquismo. Pero no así la derecha. Por decirlo con palabras del Maestro De Vega, para ésta, como en otros muchos asuntos, la llamada "transición política» no se traducía en un camino para superar los viejos agravios y lograr una auténtica reconciliación. No; para ellos, por el contrario, aquélla no fue más que «un proceso montado desde un doble lenguaje - [...]-, con el que [...] ha querido disimular un cambio lampedusiano para que todo siguiera igual».

Afirmada la constitucionalidad de la expropiación de RUMASA mediante un Decreto-ley — que, por lo demás, ya había sido transformado en Ley, que igualmente fue recurrida y cuya constitucionalidad y en este segundo recurso fuera admitida por unanimidad - , por el voto de García-Pelayo, todos los antiguos demonios regresaron a la escena política. Los viejos, e inconfesados, cargos que se esgrimieron para impedir su acceso a la Cátedra, volvían a ponerse en marcha. Ahora, se hacían públicos sin el menor recato. Otra vez, en efecto, salía a relucir su militancia socialista. Otra vez oíamos el reproche de haberse mantenido leal al Gobierno legítimo de España. De nuevo, se nos recordaba su condición de capitán del Ejército republicano. Había, sin embargo, una novedad en las acusaciones. Una que habría de doler especialmente a quien, como Manuel García-Pelayo, pretendía regirse por el principio de la virtud política maquiavélica y que, además, había dado pruebas bastantes de su honradez en todos los ámbitos de la vida. Ahora, a todo lo anterior se añadía la falacia injuriosa de que se había enriquecido gracias a su voto.

Poco importaba que atribuir el voto de García-Pelayo a las viejas acusaciones, además de ser prueba de una intolerancia poco compatible con el sistema democrático, era algo infundado y, desde luego, ajeno a la realidad, y que hacerlo respecto de la nueva era, por falso, una auténtica ignominia. De nada sirvieron, en este mismo orden de cosas, que la mayoría de los que debieron haber sido sus colegas como funcionarios docentes universitarios salieran en su defensa. En este sentido, señalaré que todos aquellos que acudan a las hemerotecas podrán encontrar allí una serie de escritos que, publicados en el diario "El País», fueron redactados por Pedro De Vega y suscritos por una gran parte de los miembros del escalafón de los Catedráticos del, todavía entonces, Derecho Político. En ellos, se 
procedía no sólo la reivindicación de la absoluta probidad del atacado, sino a la explicación del voto de éste y de su sentido: Siendo absurdo plantear un recurso de inconstitucionalidad basado en la mera formalidad (la utilización del Decreto-ley), cuando esa fuente había sido ya convertida en Ley y, en consecuencia, y como aceptaron los autores de los votos disidentes a la primera sentencia- la posible inconstitucionalidad formal había sido subsanada, el voto de GarcíaPelayo resultaba plenamente lógico. Fue, asimismo, totalmente irrelevante el que cuando D. Manuel hizo de nuevo uso del voto de calidad, con motivo del recurso previo interpuesto frente al proyecto de Ley Orgánica por el que se despenalizaban determinados supuestos de aborto, lo hiciera para declarar la inconstitucionalidad de un cuerpo normativo elaborado por la organización partidista a la que él pertenecía: el PSOE. La derecha, que en realidad era bien conocedora de todo esto, continuó con su campaña difamatoria. Se ponía, de esta suerte, en marcha un mito del que, como corresponde al toda cultura mítica y su aplicación en el ámbito de lo político, se pretendía, incluso sabiendo que no era real, extraer el máximo beneficio político posible. Y del que todavía hoy, y desde las más diversas posiciones políticas partidistas, y con las más variadas intenciones, se quieren seguir obteniendo grandes réditos en términos electorales.

Lo de menos sería detenerse aquí a señalar que, en realidad, y en el fondo, con esta infamia era todo el sistema en conjunto el que lo hacía. Aunque, sin duda, no está de más poner de manifiesto que el comportamiento político y social al que nos referimos no era una estrategia nueva, ni tampoco desconocida en nuestra Historia política. Es, al mismo tiempo, oportuno advertir que su puesta en ejecución ha sido siempre especialmente nociva y peligrosa. Lo hecho con García-Pelayo por una parte de la clase política y, junto a ésta, por una buena parte de quienes controlaban el poder económico y el comunicativo en modo alguno constituye una excepción al respecto. Los peligros que esta conducta entraña, y que hoy, más de veinte años después del inicio de su materialización, se nos antojan evidentes, justifica sobradamente el que hayamos de prestarle atención.

Estimo que no habrá grandes dificultades para reconocer que en la actitud mantenida por la derecha, política, social y económica, con motivo del pronunciamiento del Tribunal sobre RUMASA recuerda, y en mucho, a aquella estrategia que, diseñada por Herrera Oria, había desplegado la CEDA. Sobre todo en el período que va desde agosto de 1932 hasta la disolución de la Constituyente de la Segunda República — y que, en realidad, era la que, aunque con otros modos, continuó ejerciendo como parte integrante de la nueva mayoría gubernamental y hasta las elecciones de febrero 1936- No sería capaz yo de determinar el sentido de esta semejanza. Francamente, no sabría decir si esto se hacía de manera totalmente inconsciente, de suerte tal que los despiadados 
ataques al insigne constitucionalista castellano serían el resultado tanto de la ingenuidad como de una cierta coincidencia ideológica, — difícilmente cuestionable, por lo demás-, entre AP y el, por así decirlo, brazo político de la jerarquía vaticana en la España republicana, o si, por el contrario, estábamos ante una táctica consciente y deliberadamente elaborada, la cual, tomando como pretexto un voto de calidad emitido por el Presidente del Tribunal Constitucional, buscaba, de forma decidida, generar los mismos efectos que en aquella ocasión.

En todo caso, ha de ser meridiano que, con independencia de cuál puede ser mi opinión particular al respecto, no es a mí, como simple estudioso que puede, y debe, ser crítico en el examen de la realidad jurídica y política estatal, pero que, de manera obligatoria, tiene absolutamente vedado el proceder a la formulación de juicios de valor respecto de la legitimidad sobre la que descansa aquélla (Heller, De Vega), a quien corresponde realizar una tal tarea. Lo que nos interesa es, única y exclusivamente, dejar constancia de que la coincidencia existe. Circunstancia que, de modo más que lamentable, se extiende a sus resultados, que, como trataré, siquiera sea brevemente, de demostrar, no pueden considerarse más que alta y dramáticamente perjudiciales, si no definitivamente letales, para el mantenimiento, entre nosotros, de la forma política «Estado Constitucional», sin duda alguna el más perfecto y útil instrumento de liberación de los hombres.

Es menester recordar que, de una forma no muy distinta a cómo había hecho para llegar al poder la organización del totalitarismo fascista en Italia y estaba haciéndolo Hitler en Alemania -cuyas formas, por lo demás, y como mínimo, atraían especialmente al indiscutido líder de la CEDA, a la par que su estrategia era considerada desde "El Debate» como el modelo a seguir en tanto en cuanto que la misma les permitiría, continuando con la farsa de su pretendido accidentalismo, y desde el respeto formal la legalidad aunque abiertamente enfrentados a la legalidad, hacerse con el poder y, de este modo, proceder a la liquidación material de un régimen que, por republicano y continuador de las ideas democráticas puestas inicialmente en circulación por Juan de París, que fueron perfeccionadas por Marsilio de Padua y Guillermo de Ockham, y que, por último, serían llevadas hasta sus últimas consecuencias por el Maquiavelo teórico del la Democracia, garantizaba plenamente la libertad de culto, pero que había acabado con aquella situación de privilegio político, social y económico de la que habían gozado bajo la monarquía-, la derecha católica, continuando, aunque de un modo formalmente distinto, el camino iniciado en el debate parlamentario del artículo 26 de la Constitución de 1931, procedió al ataque infundado y sistemático hacia la mayoría gubernamental, y hacia quienes la integraban. Así, nos encontramos con que si a Azaña —a quien se pre- 
sentaba como fatalmente inoculado por un virus marxista, como un cripto-socialista o, en su caso, como prisionero de los socialistas-, se le acusaba de ser, bajo la apariencia de un demócrata radical, un auténtico tirano apegado al poder, y a los socialistas y radical-socialistas, —culpables, en buena medida, de la pérdida del poder de la Iglesia en la nueva República española, al ser ellos, en unión con el Partido Republicano Radical (al que, sin embargo, exculpan), quienes habían propugnado el citado art. 26-, se les suponía el deseo de establecer en España un régimen dictatorial de izquierdas, la coalición por ellos formada no saldría mejor parada. De aquella época es, en efecto, la puesta en circulación de la rara especie de que la representación política, con todo lo que ésta tiene de ficción, no es continua y permanente de elección general a elección general, sino, por el contrario, discontinua y coyuntural. De esta suerte, se defendería la tesis de que, porque un Parlamento democráticamente elegido habrá momentos en que, efectivamente, represente, y, de acuerdo con los esquemas teóricos de la democracia representativa elaborados por Sieyès, es capaz de interpretar de modo correcto la verdadera voluntad del cuerpo electoral, mientras que en otras ocasiones esto no sucede, la Constituyente, con una clara mayoría conformada por el democratismo radical y el socialismo, se había divorciado de la opinión pública, y que ello implicaba, de manera inmediata e inevitable, la obligación por parte del Gobierno presidido por Azaña, y pese a contar, al menos nominalmente, con la confianza del Presidente de la República y, de manera real, de la Cámara, de dimitir, y, en un momento posterior, la necesidad de proceder a la disolución de las Cortes. De no hacerse así, lo que sucedería es que, como se dijo en sede parlamentaria y en algún sector de la prensa, Azaña estaría secuestrando la soberanía popular.

La finalidad perseguida con una tal estrategia no podía ser, al menos a nuestro juicio, más clara. De lo que se trataba era de sembrar la duda sobre los políticos de la mayoría como mecanismo para, de un modo definitivo y total, lograr el descrédito y desprestigio de las instituciones y, con ello, el de la democracia republicana misma. El método empleado, no nos es desconocido a los estudiosos de la Política y el Estado. Bien podría decirse que, en realidad, lo que la derecha católica hacía no era más que llevar al ámbito de la práctica política aquello por lo que, como teórico del Derecho y de la Política, venía esforzándose Schmitt y que, sin disputa, alcanzó su grado máximo en su célebre Die geistesgeschichliche Lage des heutingen Parlamentarismus, su obra más ideológica y más claramente escrita a favor del establecimiento del régimen totalitario de derechas. Esto es, de lo que se trata es de llegar a la conclusión de que, porque enfrentada a un modelo ideal, y en cierto sentido mítico, el sistema democrático-parlamentario presenta no pocos problemas operativos, la Democracia resulta invia- 
ble y, en consecuencia, la única alternativa es la puesta en marcha del Estado totalitario o, en su caso, y como mínimo, el Estado autoritario.

Aunque ello parezca alejarnos de nuestro fin, creemos, sin embargo, oportuno y conveniente, tanto más cuanto que afecta al autor objeto de atención en este estudio, hacer un breve excursus sobre la tesis sostenida por Schmitt y que, como nadie puede desconocer, dio origen a una de las más lúcidas, clarificadoras, brillantes y fecundas polémicas habidas en el marco de la llamada Teoría Constitucional de Weimar, en la que tuvieron un papel destacadísimo Kelsen y Thoma. En este sentido, debemos al Maestro De Vega la observación de que si, de manera indudable, los falaces argumentos esgrimidos por Schmitt resultaban demoledores para el mantenimiento del constitucionalismo, es lo cierto que no menos nocivos y peligrosos resultaban las construcciones de quien, tratando de soslayar las trágicas consecuencias a las que conducía el discurso schmittiano, procedían a eliminar la crítica al parlamentarismo como medio de defensa del sistema democrático. Y, en este contexto, es menester proclamar que fue uno de los más grandes méritos de Heller el haber sabido enfrentarse a esta espinosa problemática de una manera cabal. Para ello, adoptaría Heller una actitud crítica respecto de las dos posturas extremas en conflicto. De esta suerte, reprocharía que negasen lo que era una verdad incontestable: la crisis de funcionamiento del Parlamento. Y ello, por cuanto que, al hacer esto, lo que hacían, pura y simplemente, era negar la posibilidad de conocer los problemas reales del parlamentarismo y, con ello, la posibilidad de articular soluciones al mismo, que sería no sólo lo que le cumple hacer a todo constitucionalista consciente de su propia función y de su responsabilidad social y política, sino también el camino adecuado para llevar a cabo la defensa de la Democracia. Por otra parte, nos encontramos con que si Heller acepta el acierto de Schmitt al apreciar la innegable crisis del Parlamento, le reprochará, no obstante, el que sobrepasara los límites de la crítica inmanente, que es la propia del teórico del Estado, la Política y el Derecho, y se situara la en el ámbito de la crítica transcendente — que es lo que, como observa De Vega, determina la parcial inadmisibilidad de toda su obra-. Así, frente a la tesis de Schmitt, afirmará Heller que admitir la indiscutible crisis de la institución parlamentaria no puede, ni debe, conducir a la afirmación de la inviabilidad e imposibilidad del sistema democrático-parlamentario toda vez que «Los defectos de la forma política no hacen más que reflejar los defectos del contenido», pero en modo alguno su crisis e inviabilidad.

Su convicción a este respecto, en todo caso, la había dejado ya clara en 1926, cuando denunció, con toda la contundencia posible, el intento del totalitarismo de utilizar la crisis parlamentaria para sustituir al régimen democrático por el dictatorial. Así, escribió Heller: «¿La crisis de la Democracia? En la historia 
de las ideas no existe una crisis de la Democracia. [...]. La Democracia en sí, es decir, esa idea dominante de que toda fuerza política o social sólo puede justificarse por la voluntad de los que están sometidos a ella, se mantiene tan firme, que sin reparo alguno puede afirmarse que hoy, fuera de la Democracia no existe otra posible legitimación del poder. [...] Lo que se haya en crisis es la técnica parlamentaria de la Democracia. [...] Fundándose en razones, tanto nacionales como socialistas, se pretende reemplazar al parlamentarismo deliberante por la Dictadura actuante. [...] La crisis del parlamentarismo es una crisis de los medios racionalistas de la democracia. [...]. A los ataques al Parlamento, [...], se unen los ataques como método democrático para la selección del personal a político. Pero este método democrático se combate también con proyectos de reforma que son, o completamente antidemocráticos o completamente inservibles».

Sea de ello lo que sea, lo que, volviendo a la estrategia de la derecha católica en nuestra Segunda República, nos interesa es dejar constancia de que la CEDA y El Debate no se encontraron solos en esta empresa. Hallaron, por el contrario, un, tan inexplicable como ciertamente efectivo, apoyo en las oposiciones republicanas. En efecto, éstas, en una actitud que no podía sino desagradar y asquear a Azaña, iniciaron un progresivo abandono del republicanismo, —entendido éste no únicamente en su dimensión relativa a la Jefatura del Estado, que no era discutido por las oposiciones republicanas, sino como un principio general de la actuación en política, y que el entonces Presidente del Gobierno, bajo una más que sobresaliente influencia de Maquiavelo y Rousseau, había definido como «Ese principio activo, propulsor, voluntario, que se empeña en corregir la realidad y moldearla según ciertas normas obtenidas por el discurso racional, es la tradición política republicana, la ideología de la revolución renaciente en los nuevos directores» del Estado-, que, en último extremo, no tenía otro objetivo que la satisfacción del principio del honor facilitando así, por un lado, las ansias de algunos por ocupar el Gobierno (Lerroux, Gordón Ordás), y, por otro, la de quien, al margen de las facultades que constitucionalmente tenía asignadas y mucho más allá de la Auctoritas de la que gozaba, pretendía dirigir efectivamente la vida política de la República (Alcalá-Zamora). Cierto es que no todos los republicanos que participaron en la llamada "obstrucción» tenían esos sentimientos, o estaban movidos por ese deseo de la gloria y el poder. Sería, por tanto, injusto atribuirles a todos ellos el haber caído en la que, de acuerdo con Heller, es la peor de las corrupciones: la corrupción política y moral. Algunos hubo que actuaron de buena fe e ingenuamente ( $v$ gr., Felipe Sánchez Román, — quien, por lo demás, trataría de encontrar alguna solución al conflicto al margen del principio del honor-). Otros, lo harían además llevados por su innegable espíritu voluntarista (Miguel Maura). Finalmente, habría también quien se vio envuelto 
en la campaña de obstrucción tan sólo por disciplina de partido, e incluso estando en contra de la misma (D. Martínez Barrio). Todos ellos, sin embargo, participarán en esta inconsciente, inoportuna e irreflexiva operación, secundando, así, la táctica ideada por la derecha católica no republicana.

Poco les importaron a las oposiciones republicanas las advertencias que, en privado y en público, el entonces Presidente del Gobierno les hizo sobre el peligro que comportaba una tal actitud. Advertencias que, de forma muy expresiva, quedaban condensadas en su célebre sentencia: «porque lo que a mí me espanta, señores Diputados — dicho sea sin reproche para nadie-, lo que a mí me espanta es que cuando estos conflictos se producen, los que agitan siniestramente sus alas son los pájaros que anidan en la noche del árbol republicano». De poco, o de nada, sirvió el que Azaña tratase de hacerles ver el sinsentido que suponía que el fundamento central de la crítica que le hacían las oposiciones republicanas, y que, siguiendo el guión trazado por Gil-Robles y Herrera Oria, llevaba a solicitar el cambio en el Gobierno, lo constituyesen las reformas que se habían llevado a cabo hasta entonces, cuyos cuerpos normativos centrales, básicos y nucleares, se habían aprobado formando ellos parte de la mayoría gubernamental. Ningún caso le hicieron los republicanos de la oposición cuando les recordaba $\mathrm{D}$. Manuel la propia lógica interna de una democracia representativa, en la que los resultados obtenidos en unas votaciones municipales, que gozan de todo su valor y de la plena eficacia en ese ámbito, no pueden condicionar de modo inmediato la configuración de la mayoría y la minoría parlamentarias, o que les recordarse que en este sistema la representación política no puede ser discontinua, sino que, al no existir el mandato imperativo, la misma se entiende conferida de elección general a elección general y que este principio, inherente al propio sistema representativo desde su inauguración en el marco de la Revolución francesa, y por el que, como indican, por ejemplo, un Heller o un Kelsen, se establece la ficción de que los representantes, que lo son de la Nación toda y no de las circunscripciones por las que fueron elegidos, conocen en todo momento la voluntad de ésta y son, además, capaces de interpretarla y actuarla de manera correcta en el Parlamento, es aplicable cualquiera que sea la naturaleza de la mayoría gubernamental.

Ningún efecto - y esto es todavía más grave — tuvo la denuncia que realizó el líder de los republicanos de izquierda sobre las implicaciones últimas que se derivaban de la política de la obstrucción. Pensaba, en este sentido, Manuel Azaña que, porque, de acuerdo con las oposiciones republicanas y no republicanas, las Cortes Constituyentes se encontraban divorciadas de la opinión pública, resultaba total y absolutamente absurdo solicitar, como haría el viejo dirigente del Partido Republicano Radical, de la Cámara un voto de confianza para formar 
Gobierno. Y, partiendo de este dato, el ya ex Presidente del Consejo de Ministros, con un lenguaje claro y contundente sacará sus consecuencias y expondrá su denuncia: «Es un poco absurdo que el Presidente del Gobierno [A. Lerroux] le diga al Parlamento, cuya confianza solicita, que el Parlamento no sirve para nada, que está desprestigiado, que está divorciado de la opinión pública, ¿para qué quiere S. S. este Parlamento? ¿para qué quiere sus votos? Esto lo juzgo un error grave de parte de S. S., [...] y así S. S., [...], viene a decir desde el Gobierno a las Cortes lo mismo que dijo en la oposición: Que el Parlamento está desprestigiado, que no representa a la opinión pública, que hay que disolverlo». En definitiva, que lo que el Presidente de la República y Lerroux, aprovechando la táctica de la derecha católica no republicana, habían hecho no es otra cosa que desenterrar la política de Alfonso XIII y los viejos partidos dinásticos respecto del decreto de disolución. Actitud ésta que, quién podría negarlo, no sólo era la contraria a las garantías que la propia Constitución había establecido para el ejercicio de aquella facultad, sino que, además, resultaba definitivamente incompatible con un régimen que, como desde la plena aceptación del republicanismo, había expresado el propio Azaña, «no será una monarquía sin rey: tendrá que ser una República republicana». Esta comprensión de la República como «República republicana» sería, como queda claro al menos desde el 29 septiembre 1930, compartida originariamente por todas las fuerzas que protagonizaron la revolución del 14 de abril. Todas ellas, en efecto, oyeron, y asintieron, al futuro Ministro de la Guerra proclamar que «la República española, por burguesa y parlamentaria que nazca, no podrá ser una monarquía sin corona. La revolución no puede consistir en el ostracismo de una familia. Nadie piense que el Estado monárquico va a persistir, sin otro cambio que la designación del jefe; [...]. Todos cabemos en la República, a nadie se le proscribe por sus ideas; pero la República será republicana, [...]. La República será democrática o no será».

$\mathrm{Al}$ no tomar en consideración las oposiciones republicanas los, indudablemente sabios y certeros, consejos de Azaña, las maquinaciones de Gil-Robles y Herrera Oria fueron tomando cuerpo. El desprestigio de las instituciones republicanas — que, sin embargo, era más aparente que real— comenzaba a calar en la conciencia colectiva, y, con ello, y al igual que había sucedido en Italia y Alemania, se generaba una sensación de caos, con la que, en último extremo, se trataba de justificar la aparición de un nuevo "cirujano de hierro» costista.

Algunos miembros de las oposiciones republicanas se darían cuenta de su error con el tiempo. Tal es el caso, por ejemplo, de Martínez Barrio. En efecto, ya en el exilio D. Diego escribiría que «Leyendo y releyendo los textos de aquellas sesiones de Cortes, he llegado a la conclusión de que nuestra actitud, [...], fue desatinada y contraria a los elementales intereses del régimen republicano. 
[...], pero en el afán de poner término a la gestión del gobierno [Azaña] elegimos el peor de los caminos. Los golpes más rudos quebrantaron el prestigio del Parlamento y dieron argumentos contra el sistema «a los pájaros que aleteaban en la noche de la República», jubilosos de comprobar que acumulábamos, multiplicándolas, todas las faltas y errores de la primera República».

Realizada la siembra, y habiendo encontrado ésta un terreno propicio en el política, social y económicamente convulso escenario del período entre guerras, en el que España no constituía una excepción, la semilla germinó. El momento de la siembra llegaría el 18 de julio de 1936. Pero los frutos de la cosecha no los recogieron, desde luego, quienes partiendo del republicanismo habían abandonado la virtud política para ejercitar, de una u otra suerte, el principio del honor monárquico. Tampoco, y pese a ser la fuerza político-partidista que más empeño había mostrado en este proceso, obtendría ganancias, o, al menos, no las esperadas, por la CEDA. Por el contrario, y como nos dicen, por ejemplo, Preston y Viñas, los que se beneficiaron en realidad fueron los partidos que nunca ocultaron su antirrepublicanismo y antidemocratismo, quienes venían no sólo manteniendo contacto con los triunfantes totalitarismos en Italia y Alemania, sino también enviando allí a sus huestes juveniles para que recibieran formación militar o paramilitar. Por asaz conocidos, no son necesarios mayores comentarios sobre los efectos de la campaña de intoxicación y que comenzaron a materializarse en la guerra civil.

Lo que nos interesa aquí, es que, como decíamos, algo parecido se puso en marcha en la España de 1978 a raíz del asunto RUMASA. Y, como entonces, con la infamia difundida no era tan sólo García-Pelayo quien sufría, sino que lo hacía todo el sistema en su conjunto. La razón es, según nuestro modesto parecer, fácilmente comprensible.

En este sentido, basta con tomar en consideración que, con independencia de que ello fuera querido o no, la campaña iniciada en 1983 por la organización conservadora, entonces llamada AP, y por una buena parte de la derecha social y económica, a quien, en realidad, acababa perjudicando era al propio sistema constitucional, favoreciendo, aunque fuese a largo plazo, los intereses de, para parafraseando a Azaña, «los pájaros que anidan en la noche del árbol» democrático. Y ello, por la sencillísima razón de que los ataques dirigidos nominalmente al primer Presidente del Tribunal Constitucional se convertían, de manera inevitable y fatal, en un ataque, y en una más que sobresaliente mengua su credibilidad, al órgano que García-Pelayo presidía, el cual, constituye la clave de bóveda del propio edificio constitucional español. Se iniciaba, así, — quiero creer que por inconsciencia, irresponsabilidad y falta de claridad conceptual derivada de los 40 años de dictadura, y no por una clara incompatibilidad con el siste- 
ma-, el camino para, al provocar el descrédito y el desprestigio del custodio constitucional, proceder a la deslegitimación del sistema inaugurado tras la muerte del general/dictador. Camino del que, pocas dudas pueden albergarse al respecto, tratarán de obtener beneficios políticos ciertos los que, desde los más variados planteamientos, podremos definir como anti-demócratas.

Importa, a este respecto, señalar que el proceso de descrédito y desprestigio del Tribunal Constitucional no terminó, ni mucho menos, con el asunto RUMASA. Ni siquiera fue este caso el único exponente o referente de su primera etapa. A él, habría de añadirse, por ejemplo, las críticas, no siempre justificadas, que, desde las más diversas posiciones político-partidistas y desde las más diferentes fundamentaciones teóricas, se iniciaron ante lo que, en mi opinión, fue un pronunciamiento técnicamente correcto, como lo fue el contenido en la S.T.C. 76/1983, de 5 de agosto, sobre la LOAPA, y su posible conversión en Ley del Proceso Autonómico.

De cualquier forma, creo estar en lo cierto si afirmo que este proceso ha llegado a su punto culminante en las Legislaturas 2004-2008 y la actual. Me refiero, claro está, e innecesario debiera ser advertirlo, al más que lamentable espectáculo ofrecido por los dos primeros partidos del espectro parlamentario cuando, con motivo de los recursos de inconstitucionalidad interpuestos contra el Estatuto catalán de 2006, procedieron al enloquecido, e indiscutiblemente perjudicial, juego de la recusación de los Magistrados, o a la falta de interés que uno y otro demuestran por lograr un mínimo consenso que permita llevar a cabo la, por lo demás constitucionalmente obligada, renovación del Tribunal Constitucional. Circunstancias éstas que, por lo que encierran o parecen encerrar: que la futura sentencia no va a ser fruto de un juicio jurídico abstracto sobre una cuestión política y que, en último extremo, no tiene por objeto más que salvaguardar el conjunto de principios y valores consagrados por el Poder Constituyente originario, suponen, de manera tan incuestionable como definitiva y fatal, un manifiesto ataque en la línea de flotación del modelo concentrado de justicia constitucional. Al fin y al cabo, nunca puede olvidarse que, como, entre otros, y con una claridad meridiana y acierto pleno, han observado Fix-Zamudio, De Vega y Schneider, la admisibilidad misma de la justicia constitucional en el marco del Estado Democrático se encuentra en que los encargados de administrarla se atengan al judicial self-restraint (autodisciplina judicial). Principio éste que ha de materializarse en dos direcciones: $1 .{ }^{a}$ ) La de limitarse a declarar inconstitucionales las normas jurídicas ordinarias que o bien, y desde un punto de vista formal, no se han atenido al procedimiento legal-constitucionalmente previsto para su aprobación o modificación, o bien, y desde un punto de vista material, contiene soluciones que de manera clara e indiscutiblemente fuera del 
haz del posibilidades abierto por el Legislador Constituyente. 2.a) Realizando razonamientos de modo tal que no surja en la opinión pública la idea, o la sospecha, de que los Magistrados leen en el texto de la Constitución lo que el Pouvoir Constituant no quiso decir, o la de que sus fallos, que son jurídicos, se encuentran exclusivamente motivados por razones político-ideológicas partidistas.

Las nefandas y nefastas consecuencias de este proceso de descrédito/deslegitimación del Tribunal, ya las estamos viendo hoy. Piénsese, en este sentido, y en primer término, en el hecho de que habiéndose declarado por unanimidad la inconstitucionalidad de la Ley vasca 9/2008, y habiendo actuado, en términos generales, el Tribunal Constitucional de forma absolutamente correcta tanto desde la concepción del positivismo jurídico formalista, como desde la del antiformalismo jurídico democrático o desde la óptica política, el nacionalismo conservador vasco interprete la S.T.C. 103/2008, de 11 de septiembre, como una auténtica operación política de agresión al Pueblo vasco por parte de las fuerzas partidistas estatales $y$, en consecuencia, y tratando, de manera absolutamente injustificada, de crear la imagen de que sería de aplicación el llamado Derecho Internacional Humanitario, anuncie, sin que se cumpla en realidad ninguno de los requisitos exigidos al efecto, un recurso ante el Tribunal Europeo de Derechos Humanos presentándose como "víctima» de aquella sentencia. La misma consideración merece, en nuestra modesta opinión, la actitud del nacionalismo catalán -más o menos progresista o más o menos conservador, pero siempre romántico, mítico y místico-, conforme a la cual, olvidándose de que, como muy bien afirmó Heller, sólo valen como Derecho Positivo aquellas normas que, además de haber sido aprobadas por la autoridad competente y con respecto a todos los trámites y requerimientos procesales previamente establecidos, son conformes con el sistema de principios y valores que actúan como criterios fundamentadores, vertebradores y articuladores del sistema político y que, por ello mismo, se encuentran respaldadas por la voluntad soberana del Poder Constituyente, no admitirá nunca una declaración, total o parcial, de inconstitucionalidad del nuevo Estatuto catalán, que, aunque fuente atípica, es tan sólo una norma jurídica ordinaria, creada por los poderes constituidos, y que se encuentra subordinada a la Constitución de 1978. Lo que, de modo inevitable, habrá de excitar sobremanera, y en ese lamentable proceso, tan combatido, por lo demás, por Azaña al menos desde 1911, de retro alimentación, al nacionalismo españolista, con todos los peligros que, nadie puede ignorarlo, ello conlleva.

Sea de ello lo que sea, lo que, aquí y ahora, nos interesa es la cuestión de cómo afectaron estos, tan injustificados como profundos, ataques al hoy nuestro homenajeado. Y en este sentido, nos encontramos con que, asqueado, supongo, por esta situación y viéndose totalmente indefenso, García-Pelayo presentó su di- 
misión como Presidente del Tribunal Constitucional en 1986. De esta suerte, y si es que en realidad la había perdido, D. Manuel recuperaba su condición de vencido. Como tal acudió a Salamanca a ser investido Doctor Honoris Causa por su Universidad, en un acto que, por no ser ya miembro del custodio constitucional, bien podríamos definir como íntimo, y que fue la única ocasión en la que yo vi en persona a aquel ilustre constitucionalista castellano. Poco después, y también como vencido, regresaría a Venezuela, donde, olvidado por las autoridades españolas, el 25 de febrero de 1991 le alcanzaría la muerte.

En tales circunstancias, evidente resulta que, aunque pueda compartirse la opinión de Rafael Degollada, conforme a la cual «La persecución [...] no envilece, no infama: honra al perseguido, como honraron a Fenelon, a Rousseau, a Lamennais, a Cabet y a nuestro Jovellanos las que sufrieron; como honra a Porlier, Lacy, Riego, Torrijos, Xaudaró y otros la muerte a que les condujo su amor a la libertad", reparar, siquiera sea moralmente, esta infamia es, como decía al comienzo de estas páginas, un acto de justicia. Haberlo comprendido así, hace que los Profesores Torres y Tajadura sean merecedores de los más sinceros y encendidos reconocimientos. En todo caso, valgan estas páginas como mi modesto homenaje a García-Pelayo, y, en él, a todos los «vencidos» que fueron, son y serán en esta España de la Constitución de 1978.

\section{2.- MARZO DE 1933, UNA FECHA CLAVE EN LA VIDA DE HELLER: LA MARCHA AL EXILIO.}

El marzo de 1933, Heller se encuentra en Inglaterra. Su estancia allí, se debía a haber sido invitado a pronunciar algunas conferencias en la London School of Economics y en la Universidad de Oxford. El hecho no resultaría de una especial relevancia, si no fuera porque fue en ese momento, y en ese espacio geográfico, cuando Heller, como consecuencia directa e inmediata del acceso, el 30 de enero, de Hitler al poder, iniciaba su exilio.

Si ello no constituyese un evidente sarcasmo, podríamos decir que en un primer momento, y por un período que se extiende desde marzo a primeros de septiembre, el abandono de su patria revistió la forma de un apartamiento voluntario. Esto es, su decisión inicial se debe más a consideraciones sobre la dinámica política de la República alemana de 1919, que a la existencia de decisiones normativas que le afectasen directamente. De una manera más precisa, estando éste en el Reino Unido, algunos de sus amigos hicieron conocer a Heller sus, en modo alguno infundados, temores sobre la suerte que el políticamente activo militante socialista y muy brillante académico podría correr en el marco de 
una Alemania gobernada por Hitler, la cual sólo desde una óptica formal podría entenderse como continuadora de aquélla República democrático-parlamentaria regida por el Texto de Weimar con la que tan comprometido estaba nuestro autor. Temores que, en última instancia, les condujeron a sugerir a Heller que no debía retornar a Alemania.

El insigne estudioso del Estado, la Política y el Derecho aceptaría el consejo de sus amigos, alemanes y no alemanes. Entre estos últimos, el de Harold Lasky, con quien tan crítico había sido Heller en su monografía sobre «La soberanía», y que, sabiendo entender que la discrepancia académica no ha de conllevar el odio personal, tanto le ayudaría en los primeros momentos de su exilio.

\section{3.- CONSIDERACIONES TEÓRICO-IDEOLÓGICAS OBJETIVAS QUE JUSTIFICABAN LA DECISIÓN HELLERIANA DE NO RETORNAR A ALEMANIA}

Entendemos, no obstante, que no es demasiado aventurado conjeturar que Heller hubiera llegado a la misma decisión por sí solo, incluso aunque nadie le hubiese advertido al respecto. Lo que se explica atendiendo a la grandísima inteligencia de la que gozaba Hermann Heller. En base a este dato, creemos que éste no podía desconocer el riesgo que para él implicaba el ascenso del Partido Nacional-Socialista al poder y, además, la aprobación, — por unanimidad en el Reichsrat, y por 441 votos contra 94 en el Reichstag- , de la Ley por la que se atribuían plenos poderes a Hitler. Aunque, en realidad, no deja de ser una mera especulación, creemos que, empero, resulta posible justificar nuestra afirmación atendiendo tanto a la propia trayectoria personal de Heller como ciudadano, como tomando en consideración las construcciones teóricas e ideológicas que había elaborado aquél.

\section{1- La derogación fáctica del Texto Constitucional como motivo objetivo y general para ponerse a salvo del totalitarismo nazi}

En este sentido, nos encontramos con que resulta muy poco creíble que Heller necesitase del aviso de sus amigos para conocer cuál iba a ser el futuro de la Constitución de 1919 con la llegada al poder de una fuerza del totalitarismo fascista. Él lo había observado, y lo había denunciado, en el supuesto de la Italia gobernada por Mussolini. Siendo, como era, Mussolini en ese momento, y hasta 1936, objeto de la admiración de Hitler que, pese a que el Duce le mos- 
traba una y otra vez su desprecio y se complacía en humillarle, lo había elevado a la condición de modelo paradigmático, no le habría de ser difícil a Heller imaginar que el dictador alemán se comportaría de un modo idéntico, o similar, a como lo habían hecho los fascistas en Italia.

Como científico que trabaja con la realidad estatal y que encuentra en ésta su objeto de estudio, conocía perfectamente Heller la singular atracción que ejercían en los totalitarismos ascendentes las construcciones, siempre -incluso en los supuestos de aquéllos que trataban de utilizar el Derecho como mecanismo de defensa de la Democracia - acríticas y avalorativas, del positivismo jurídico formalista, preocupado, según la clásica definición de Dicey, en explicar lo que la Constitución dice y no lo que la Constitución significa. Circunstancia ésta que, si bien, en tanto en cuanto que se trataba de corrientes ideológicas que negaban, de manera absoluta y total, los principios y valores en que se funda el Estado Constitucional y, además, se encontraban inspiradas, en mayor o menor medida, en la filosofía irracionalista de los Schopenhauer, Nietzsche y Bergson, y en la de la decadencia de Spengler, fuente, a su vez, de la doctrina de la exaltación de la violencia en la política de Sorel, puede resultar extraña. Ello no obstante, ocurre que, como ha puesto de relieve el Maestro De Vega, la misma no es difícil de comprender. Basta, en este sentido, con tomar en consideración que, desde los esquemas conceptuales puestos en marcha por la Escuela Alemana de Derecho Público, y pese a la depuración de los mismos operada por el positivismo posterior, de un modo muy particular en los escritos de Kelsen, a lo que el positivismo jurídico formalista conducía era a la forja de un Derecho Constitucional que, falsificado en sus presupuestos centrales y basilares - de forma fundamental en lo que se refiere a la teoría democrática del Poder Constituyente del Pueblo y sus consecuencias-, y evadido de la realidad y de la Historia, acababa presentándose como un verdadero absurdo y esperpéntico complejo conceptual, destinado a teorizar y justificar un constitucionalismo ficticio «que terminaba no siendo constitutivo de nada, ni siquiera la del Estado», y con el que, en última instancia, únicamente se pretendía ocultar a las relaciones reales de poder en la Comunidad Política.

De esto es, como con acierto comprendió Heller, de lo que, con una grandísima habilidad y astucia, supieron aprovecharse los totalitarismos fascistas. A los dictadores fascistas les interesaban, y sobremanera, las tesis del positivismo jurídico formalista por cuanto que las mismas les permitirían dar cobertura legal, que no legítima, a cuantas acciones y tropelías quisieran llevar a cabo, sabiendo, en cualquier caso, que podían seguir afirmando que se atenían a las reglas del Estado de Derecho, y que, desde, por ejemplo de ingenuidad kelseniana de que éste era posible con independencia del contenido ético, político y social de que 
se le dote, su aserto no sería desmentido por los académicos. La razón de que esto fuera así, se encuentra, en última instancia, en el propio concepto de Derecho Positivo mantenido por las escuelas positivistas. En efecto, reducida toda la problemática del Derecho Constitucional a una simple cuestión de formas, el positivismo jurídico formalista, que renunciaba a tomar en consideración los principios y valores que, consagrados por el Pouvoir Constituant, informan el ordenamiento por considerar a éstos, como datos políticos, ajenos al mundo jurídico, y de un modo muy distinto a como, ya lo hemos visto, hacía el antiformalismo democrático helleriano, reducía el Derecho Positivo, y su validez, al mero dato de que las normas jurídicas fuesen aprobadas con su correspondiente nomen iuris, por el órgano jurídicamente competente y, desde luego, con observación del procedimiento previamente establecido al efecto. Satisfecho este requisito, que era lo que les importaba a los positivistas formalistas, no habría dificultad en que los Profesores de Derecho Constitucional, a quienes, pese a las críticas formuladas por Jellinek, les estaba vedada la formulación de juicios de valor, se aviniesen a actuar como meros justificadores de los hechos. Al fin y al cabo, esto era lo que se derivaba, como, con meridiana claridad denunció Triepel, de aquella falaz, acientífica y absurda idea de que, como realidades independientes, existen una verdad histórico-política y una verdad jurídica que aunque pueden llegar a coincidir no tienen, en rigor, por qué hacerlo. Si a esta vieja contraposición, se le une el que los académicos positivistas del período entre guerras iniciaron la práctica de la defensa de una verdad de lo políticamente conveniente, las consecuencias no pueden ser más evidentes. Convertido el Derecho Constitucional en un mero instrumento técnico al servicio del poder al que, por quedar al margen, y muy en contra de lo que sucedía con el resto de las ramas jurídicas, de la crítica y del juicio valorativo referido a los principios y valores, podía hacérsele decir cualquier cosa, los totalitarismos fascistas encontraban en el llamado método jurídico puro un excelente aliado para llevar a cabo sus fines. Y ello, por la sencillísima razón de que nunca más que las dictaduras fascistas se ha hecho más real el que, por decirlo con De Vega, «el razonamiento instrumental del jurista a lo único que puede conducir es a convertir su oficio en ese menesteroso quehacer que ya describió Federico de Prusia cuando, dirigiéndose a sus generales, les dijo aquello de "vosotros conquistad sin recato, que ya vendrán los juristas con argumentos para justificaros»"».

Si esto es así en términos generales, en su estudio/denuncia del régimen político de Mussolini, puso de manifiesto Heller que el Duce y los juristas a su servicio mostraron un particular, y más que sobresaliente, interés por una de las construcciones del primer positivismo jurídico formalista, que afectaba de modo directo e inmediato a la vigencia y efectividad mismas del Texto Constitucional. 
Nos referimos, claro está, a la concepción que tenían Laband y Jellinek sobre ese fenómeno que bautizaron con el término de "Wandlung» o «Verfassungswandlung», traducido al castellano, precisamente por García-Pelayo, como «mutación constitucional».

La atracción especial que el fascismo, como posteriormente el nazismo, sentía hacia estas formulaciones, es algo que, según nuestro modesto parecer, siempre de acuerdo con la certera, cabal y ponderada denuncia realizada por Heller, a nadie puede sorprender. En el fondo, lo que sucedía es que los gobernantes fascistas, contando con la inestimable colaboración de no pocos juristas, supieron, de una manera innegablemente hábil, servirse de aquellas construcciones sobre la Wandlung para llevar a cabo, con el respeto formal a la legalidad, y desde la propia legalidad constitucional, la destrucción de la Constitución y la total aniquilación de la estructura constitucional del Estado italiano. Veámoslo con algún detenimiento.

De todos es, o, al menos, debiera ser, sobradamente conocido que aquellos dos insignes integrantes de la Escuela Alemana de Derecho Público comprendieron la Verfassungswandlung como cualquier situación de incongruencia, o discordancia, entre la realidad jurídico-normativa, que es la que se expresa en el texto del Código Jurídico-Político Fundamental, y la realidad político-social que la Ley Constitucional pretende regular y conducir. Incongruencias éstas que, como señala Jellinek, se derivan de la actuación de las «fuerzas políticas reales [que] operan según sus propias leyes [y] que actúan independientemente de cualquier forma jurídica». La verdadera importancia de este fenómeno radica en que, por aquella discordancia, los preceptos del Texto Constitucional se ven, como indica Hsü Dau Lin, obligados a regular circunstancias distintas a las que originariamente habían sido imaginadas. Lo que, en último extremo, se traduce en que, en la medida en que «el contenido de las normas constitucionales, [...], manteniendo el mismo texto, recibe una significación diferente» (K. Hesse), la mutación acaba por generar una transformación no formal de la Constitución como la cual tan sólo cabe explicar como el resultado del fait accompli, o fuerza normativa de los hechos, comprendido éste, como lo hacía Jellinek, como un fenómeno histórico con fuerza constituyente.

No es éste, obviamente, el momento oportuno para detenerse a enjuiciar la decisiva importancia que ha tenido el fenómeno de la mutación constitucional como mecanismo para el efectivo mantenimiento de las Constituciones. Papel que en modo alguno, y como, entre otros, ha puesto de relieve La Pergola, es insignificante. Tanto es así, que no ha faltado quien, como, por ejemplo, Durand, haya afirmado que, atendiendo a la función actualizadora del Texto que tiene su actuación, el juez constitucional, como supremo, que no único, intérprete del 
Código Jurídico-Político Fundamental y sujeto más importante en la generación de la Wandlung, puede ser concebido como una suerte de Poder Constituyente «secundario». El supuesto de la Constitución estadounidense es, sin disputa, un magnífico ejemplo de ello, y, por ser harto conocido, nos exime de mayores comentarios al respecto.

De cualquier modo, no podemos dejar de consignar, a este respecto, que no le falta razón al Maestro De Vega cuando llama la atención sobre el hecho de que, ya desde las formulaciones de Jellinek, la mutación se presenta como un instrumento jurídico político básico y fundamental para que, aunque de un modo bien distinto al de la Verfassungsänderung, el Derecho Constitucional positivo pueda satisfacer la obligada dinamicidad que le impone la propia realidad política y social. Es, en efecto, una afirmación generalmente aceptada entre los constitucionalistas la de que la Verfassungswandlung es un instrumento complementario y, a la vez, excluyente de la técnica de la reforma del la Constitución el contexto de la dialéctica estática y dinámica constitucionales, el cual, además, ha terminado por desplazar de algún modo a la segunda, en el sentido de que la puesta en marcha del amending process tan sólo se plantea cuando las posibilidades de operar una mutación se han agotado.

Lo que en realidad nos interesa, aquí y ahora, es advertir que, concebida de aquélla manera la Wandlung, los mismos Laband y, mucho más, y no por casualidad, Jellinek hubieron de enfrentarse a la problemática de la validez de las mutaciones constitucionales. De una manera más concreta, de lo que se trataba era de determinar qué debía hacerse prevalecer una vez que la incongruencia entre la realidad jurídico-normativa y la realidad político-social se presenta en términos de radical y absoluta incompatibilidad y oposición manifiesta, si la norma constitucional o el fait accompli.

La respuesta que el primer positivismo jurídico formalista dio a este interrogante fue, bien conocido es, claramente favorable a la segunda alternativa. Esto es, comprendido el fait accompli como un fenómeno histórico con fuerza constituyente «frente al cual toda oposición de las teorías legitimistas es, en principio impotente», evidente resulta que habrá de ser la fuerza normativa de lo fáctico la que deba prevalecer en caso de conflicto o entre norma constitucional y realidad político-social. Con ello, lo que hacía la Escuela Alemana de Derecho Público era decretar que cualquier cambio no formal del Código Constitucional, incluso si el mismo se encontraba en franca oposición con el texto de la Constitución y el conjunto de principios y valores insitos en él, habría de reputarse válido y lícito. Y sería el ingenio de Jellinek, — sin discusión alguna, el más inteligente, válido, capaz y útil de todos los que formaban parte originariamente de aquel grupo-, el encargado de explicarlo. No otra cosa significan, en efecto, sus 
palabras, conforme a las cuales si los operadores jurídicos y políticos del Estado aceptan aquella transformación constitucional, «no hay medio alguno para proteger a la Constitución contra una mutación ilegal debida a una interpretación ilegítima».

$\mathrm{Ni}$ que decir tiene que esta respuesta puede parecer extraña y sorprendente. Sobre todo, la misma lo es en boca de quienes, como académicos, afirman que toda la rica problemática del Derecho Constitucional empieza, se desarrolla, y culmina en el texto de la Constitución, y sólo en ella, y que no ha lugar en el estudio de la misma a consideraciones de carácter político y sociológico. Ello no obstante, es menester advertir que la misma se encuentra, de manera tan plena y absoluta como incuestionable, en total y perfecta consonancia y coherencia con los presupuestos metodológicos y políticos sobre los que se formuló aquel constitucionalismo monárquico, que, habiéndose iniciado, de manera vergonzante, por Hegel con su teoría de la soberanía del Estado, y, decididamente, por Stahl, alcanzaba su máximo apogeo y esplendor con la obra de la Escuela Alemana de Derecho Público, y de un modo muy particular con la de Laband.

$\mathrm{Ha}$ de recordarse que una de las consecuencias más evidentes, $-\mathrm{y}$, al mismo tiempo, más perniciosas y nefastas para la fortuna de la forma política «Estado Constitucional»—, es la de que al afirmar que la soberanía reside en el Estado, lo que en realidad se hacía, — de un modo bien diverso a como lo había concebido Hegel para había de conciliarse la soberanía del príncipe y la del Pueblo—, era configurar al monarca, en cuanto que Jefe del Estado, como el verdadero titular de la soberanía y, en consecuencia, como un sujeto legibus solutus en el marco del Estado ya constituido. Consecuencia ésta a la que, como con meridiana claridad denuncia Heller, no pudo substraerse ni siquiera Jellinek. Y este principio sería el que informaría el Derecho Constitucional alemán hasta el proceso revolucionario de 1918-1919, en el sentido de que el «manual más extendido, el de Meyer- Anschütz, recalca que el monarca reúne en su persona «todo el poder del Estado", y en la última edición, publicada antes de la Revolución [alemana], se sostenía la opinión de que la Constitución prusiana no se fundaba [...] en el principio de la división de poderes. [...]. Toda función del Estado se deriva de su poder [del rey], aunque la transmitiera órganos permanentes» (Heller).

Se comprende, de esta suerte, y aunque pueda parecer paradójico, la nada desdeñable contribución del positivismo jurídico pre-weimariano al mantenimiento de aquella falta de eficacia jurídica de los Textos Constitucionales que, como está generalmente admitido, caracterizó la vida del Estado Constitucional liberal en Europa. Lo que, de una manera muy básica y fundamental, se explica por su afirmación del monarca como soberano no sólo en el momento de aprobar y sancionar el documento de gobierno, sino también una vez éste ha entra- 
do en vigor. Fue, en efecto, su empeño en dar entrada en el esquema de la Comunidad Política ya constituida a un sujeto soberano que, además, actúa como tal en todo momento y que, por ello mismo, se sitúa por encima del Código Jurídico-Político Fundamental por el que aquélla se rige, lo que contribuyó, en modo más que sobresaliente, no ya a que, como sostiene Carré de Malberg, el instrumento de gobierno no pudiera ser entendido como una auténtica norma jurídica a la que le corresponde la condición de Lex Superior. En realidad, y como, con la brillantez y rigor que siempre le caracterizan, ha hecho ver Pedro De Vega, lo que se derivaba de aquellas construcciones era que, siendo innegable el reducido alcance normativo de los Códigos Constitucionales liberales, «esa escandalosa carencia no se produjo porque las Constituciones no fueran leyes (que por supuesto lo eran), sino porque no se configuraron ni se entendieron propiamente como Constituciones».

Es, lógicamente, y en cualquier caso, desde la óptica anterior desde donde nuestra afirmación sobre la coherencia política de las tesis de Laband y Jellinek, adquiere su sentido pleno. La razón no ha de ser muy difícil de comprender. Concebido, en 1870, el constitucionalismo monárquico como un instrumento con el que no se defendía los intereses nacionales alemanes y/o los prusianos, sino, en primera instancia, los del Kaiser Guillermo y, en segundo término, los de la Internacional monárquica (Heller), y tomando en consideración que la mayoría de los supuestos de las que Jellinek llamaba mutaciones ilegales se debían a la voluntad, que ellos consideraban ilimitada, del monarca y, siempre, tenían lugar en favor de éste, nada de extraño tiene que tanto Laband como el ilustre insigne Maestro de Heidelberg se apresuraran a afirmar la validez, licitud y legitimidad de cualquier supuesto de Wandlung.

No hace falta ser demasiado perspicaz, ni realizar un gran esfuerzo intelectual, para comprender el enorme, dramático y trágico embate que una tal concepción de la mutación supone para la vigencia efectiva del dogma jurídico de la supremacía constitucional. Superior, desde luego, del que se deriva del concepto científico, estricto, moderno y técnico de la mutación constitucional, que es el que se pone en marcha con la publicación, en 1932, del trabajo de Hsü Dau Lin, en el que, habiendo sido elaborado desde las observaciones realizadas al respecto por Heller y, fundamentalmente, por su Maestro: Rudolf Smend, se inicia la comprensión de la Verfassungswandlung como una facultad constitucional limitada por la propia Constitución interpretada. Que ello sea así, es muy fácil de entender. Basta con tomar en consideración que la idea de que, como se dijo en la tradición jurídico-constitucional estadounidense, y desde el primer momento, la Constitución es el Derecho supremo del país (art. VI,2 Const. Estados Unidos de América de 17 de septiembre de 1787), que arranca de la clara 
y definitiva aceptación del dogma político de la soberanía del Pueblo, sólo devendría realmente eficaz cuando, en virtud del principio de rigidez constitucional, y estando éste asegurado por algún mecanismo de control de constitucionalidad, hizo su entrada en escena, y adquirió autentica entidad y efectividad, la doble distinción entre, de una parte, Poder Constituyente/Poder de revisión constitucional/Legislador ordinario, y, de otra, la de Ley Constitucional/Ley de reforma de la Constitución/Ley ordinaria.

De cualquier modo, lo que a nosotros interesa ahora es que, haciendo primar la fuerza normativa de lo fáctico incluso sobre la voluntad soberana del Legislador Constituyente, tanto Laband como Jellinek hacían inviable el que pudiese llevarse a cabo la distinción entre las diversas manifestaciones de las transformaciones no formales de la Constitución, y, con ello, la de determinar la validez e, incluso, posibilidad misma de aquéllas. Diferenciación ésta que, como ningún estudioso del Derecho, el Estado y la Política puede desconocer, resulta básica en el marco de un Derecho Constitucional que, como el que se había iniciado en Europa con la Constitución alemana de 1919, estaba construido, como no podía ser de otra forma, sobre el principio democrático. La misma, por lo demás, -y no es ocioso recordarlo en la coyuntura jurídica y política por la que atraviesa la España de los primeros años del siglo XXI-, ha gozado de una aceptación doctrinal prácticamente unánime desde la formulación del concepto científico, moderno, estricto y técnico de mutación constitucional hasta que, como consecuencia de las mal llamadas «revoluciones conservadoras» de los años 1980, aquel principio ha empezado a ser discutido, si no — y desde la admisión incondicionada de las posiciones del más radical de los positivismos jurídicos, encarnadas, por ejemplo, en las tesis de Preuss y Kelsen- negado de manera definitiva, en aras a la construcción de una «aldea global» neoliberal.

Se trata, obvio ha de ser, de la contraposición entre Verfassungswandlung y faussement de la Constitution. Para una Teoría Constitucional, como era la que se inició en la época de Weimar y que se consolidaría a partir de 1945, -articulada en torno al triple principio de $1 .^{\circ}$ ) que la voluntad soberana del Pueblo determinada, de acuerdo con el principio mayoritario (Heller), en el momento del pacto social se impone, como estableció el reverendo Wise en la que se considera, y con razón, la primera teorización del proceso constituyente, a todos, incluso a quienes discrepen de ella, y que es al contenido de aquella voluntad soberana a lo que han de estar todos; $2 .^{\circ}$ ) que, como advertiría Rousseau, la propia lógica interna de la Democracia (entendida ésta, desde los esquemas conceptuales maquiavélicos, como Libertad, Igualdad y Justicia), exige la más escrupulosa observancia de las leyes que el mismo Cuerpo Político se da libremente, y que esta obligación es particularmente exigible a los gobernantes, y $3 .^{\circ}$ ) 
que, por último, la Constitución, y, con ella, todo el Derecho Positivo que existe en su virtud, tan sólo perderá el carácter de norma jurídica obligatoria y vinculante cuando la mayoría del Pueblo como unidad deje de identificase con los principios y valores que fueron positivizados en aquélla por el Pouvoir Constituant y, en consecuencia, decida embarcarse en un nuevo proceso revolucionario-, la mutación, en cuanto que modificación no formal del Código Fundamental debida, según la conocida expresión de Jellinek, a la actuación de fuerzas cuyo sometimiento al Derecho sería un esfuerzo inútil, ha de dejar de ser, de forma tan necesaria como inevitable e ineludible, entendida como una facultad extrajurídica e ilimitada en poder de los operadores jurídicos y políticos, para pasar a ser comprendida como una facultad constitucional y, por ello mismo, limitada. Las consecuencias se derivan de ello son, a nuestro juicio, meridianas. En efecto, porque la Wandlung es una facultad constitucional, que se verifica dentro del Texto Constitucional y por unos sujetos que bajo ningún concepto pueden ir en contra de lo que el Legislador Constituyente ha establecido en el Código Jurídico-Político Fundamental, evidente resulta que todo supuesto de auténtica mutación constitucional —es decir, en aquellos supuestos en que los preceptos constitucionales reciben, merced a la interpretación constitucional, una significación distinta a la que originariamente tenían pero, en todo caso, y esto es lo realmente importante, compatible con aquél— será, y ha de ser reputado como tal, válido, lícito o y legítimo.

Todo lo contrario sucede con los supuestos de falseamiento de la Constitución. Advierte, en este sentido, y con total acierto, claridad y contundencia, el Maestro De Vega que con este término «se alude al fenómeno en virtud del cual se otorga a ciertas normas constitucionales una interpretación y un sentido distinto de los que realmente tienen. Su tratamiento se conectaría [...] con la simple transgresión de la misma (Verfassungsüberschreitung)». Siendo así, tampoco puede caber duda alguna sobre el dato de que, en tanto en cuanto nos encontramos en presencia de una, más o menos patente, más o menos encubierta -apelando, para ello, a los más sólidos argumentos del positivismo jurídico formalista-, vulneración de la voluntad del Poder Constituyente originario, el faussement de la Constitution nunca, y bajo ningún concepto, podrá ser comprendido como una operación válida, lícita y legítima. Ni siquiera, y esto adquiere una singular transcendencia en nuestros días y en el marco de la vigencia de la Constitución española de 1978, cuando aquél sea de algún modo amparado por la decisión del supremo custodio constitucional.

Como decíamos, esta distinción, que es básica, central y medular para el mantenimiento de la forma política "Estado Constitucional», era imposible de realizar en la teoría de la mutación constitucional debida a la Escuela Alemana 
de Derecho Público. Lo que no es difícil de comprender. Ajenos al verdadero sentido y significado del principio democrático, y, en consecuencia, a sus corolarios, uno y otro supuesto de transformación no formal del Código JurídicoPolítico Fundamental, que, por lo demás, quedaban identificados, habrían de tener la misma consideración. Los dos supuestos, Verfassungswandlung y faussement de la Constitution, serían admitidos como válidos, lícitos y legítimos.

Esto es, como tuvo ocasión de observar Heller, lo que interesaba a Mussolini. Y es, también, esta circunstancia de la que - de un modo indiscutiblemente mucho más hábil, $\mathrm{y}$, de cualquier forma, mucho más coherente con las pretensiones del totalitarismo fascista del período entre guerras, que aquel apócrifo, y repudiado, remedo español que había procedido a la derogación de la Constitución de 1876 - supo aprovecharse el dictador italiano. Téngase en cuenta, a este respecto, que la apelación a la concepción de la mutación constitucional de Laband y Jellinek adquiere su pleno sentido, y cobra su auténtica entidad, en tanto en cuanto que, gracias a ella, y a pesar de que, en un ataque de sinceridad, Mussolini llegase a proclamar, como hizo el 12 de mayo de 1928, en el Senado que "La Constitución ya no existe», podía, sin embargo, esconder sus vergüenzas ante la sociedad internacional y ante sus propios súbditos — que no ciudadanos- al poder presentarse ante ellos, y con la bendición del positivismo jurídico formalista radical, como gobernantes democráticos. Se daba, así, satisfacción plena a la que, sin disputa, era una de las mayores obsesiones de los totalitarismos del período que entre guerras, y muy particularmente de los de derechas. A tal fin, e interesa recordarlo, estaban destinadas las especulaciones teóricas, intelectuales y científicas, o pseudo-científicas, de Schmitt. Su argumento, no podría ser más contundente, aunque, como ya se ha visto, tampoco más erróneo. A saber: porque la democracia liberal real muestra no pocos defectos en su funcionamiento respecto de un inexistente y mítico modelo ideal, y, por ello mismo, y en tanto en cuanto aquéllos son graves, ha de tenerse como absoluta, innegable y definitivamente inviable, lo que sucede, dirán los partidarios del totalitarismo, es que sólo la dictadura fascista puede reclamar para sí la condición de ser la verdadera, perfecta y única realmente realizable democracia. Idea ésta que se encargarían, ya en el plano de la política práctica, de difundir los «jefes» de las fuerzas fascistas. Recuérdese, a este respecto, que todavía en 1937, estando en Berlín y en compañía del Führer, Mussolini, sin recato alguno, proclamaba que «Las dos democracias más grandes y más auténticas que existen hoy en el mundo son Alemania e Italia».

El papel jugado por el positivismo jurídico - incluso aunque fuera de forma involuntaria, pero no por ello disculpable - en esta farsa en modo alguno fue insignificante. En este sentido, debe tomarse en consideración que, aunque 
desde un punto de vista político y jurídico, el resultado de lo hecho por Mussolini era el mismo que el que se derivaba de la actuación de otros dictadores, como, por ejemplo, Primo de Rivera, y que, en relación con sus respectivas opiniones públicas, en ambos casos la monarquía había perdido mucho de su prestigio, otra cosa muy distinta ocurría cuando toda la rica problemática de la vida jurídica y política del Estado se reduce a un conjunto de reglas lógico-matemáticas y geométricas. Desde este punto de vista, ambos supuestos adquirían una significación muy distinta. Y ello, por la sencillísima razón de que el primero, que en realidad también destruía el régimen constitucional, no había procedido a la derogación del Código Jurídico-Político Fundamental.

Se comprende, de esta suerte, que, en Italia, el dictador fascista tuviera la pretensión, y, por qué no decirlo, la desfachatez, de presentarse ante la opinión pública nacional e internacional como un gobernante democrático. Se entiende, asimismo, - y con una mayor transcendencia en cuanto a la ponderada y cabal comprensión de esta problemática desde lo que ha de ser la función del constitucionalista como jurista encargado de explicar un Derecho basado en las ideas de Democracia y Libertad-, que el Duce tuviera una absoluta confianza en que su grosera falacia no sería desmentida por los juristas del positivismo formalista. Al fin y al cabo, sucedía, por un lado, que, al no haber derogado de iure el Estatuto albertino, bien podía aparentar el dictador que su actuación gubernamental se desarrollaba en el marco, y con una escrupulosa observación, de una Constitución. Por otro, ocurre que, estando ésta formalmente en vigor, nada importaba desde los esquemas conceptuales puestos en marcha por Laband y Jellinek, que, con la falsificación continuada, y totalmente voluntaria, de las normas constitucionales, se procediera a la puesta en marcha de un régimen político nuevo que, en rigor, —y como, con acierto y contundencia, había hecho ver Heller-, nada tenía que ver con el que existía cuando el fascismo ascendió al poder.

Nada quedó, en efecto, y gracias a la utilización de la comprensión de la Verfassungswandlung como una facultad extra e, incluso, contra constitucional ilimitada, del viejo edificio diseñado por el Estatuto italiano de 1848. Y, de manera hoy innegable, esto sucedía en todos los extremos regulados por aquél.

En este sentido, es menester comenzar indicando cómo lo anterior se produjo, y de un modo más que patente, en relación con la llamada "parte orgánica» del Texto Constitucional. De una manera mucho más concreta, esta supresión fáctica del instrumento de gobierno adquiría una especial y singular realidad en cuanto al principio de división de poderes, y, con ello, se llevaba a cabo un ataque mortal a la posibilidad misma de la forma política «Estado Constitucional». La razón es fácilmente comprensible, y, según nuestro humilde parecer, no existe obstáculo alguno para que todos los constitucionalistas de hoy —cual- 
quiera que sea el método de estudio que adoptemos: positivismo jurídico positivista o jurisprudencial; positivismo sociológico decisionista, institucionalista o realista, o, finalmente, el antiformalismo democrático helleriano- estemos de acuerdo en ello. Veámoslo.

Ha de ser para todos un axioma indiscutido, e indiscutible, el que, como, por ejemplo, han puesto de relieve Schmitt o De Vega, el Estado Constitucional, y la posibilidad misma de su subsistencia, descansa en la idea de que habiendo sido creada, fundada o refundada la Comunidad Política por un sujeto soberano, el «Pueblo como unidad» del que hablaba Heller, una vez que aquélla ha sido organizada por la actuación del Pouvoir Constituant, este último ha de desaparecer de la escena política, entrando en una fase de letargo de la que sólo saldrá cuando la totalidad o, al menos, la mayoría de los ciudadanos estimen oportuno darse un nuevo Código Jurídico-Político Fundamental. Se da paso, de esta suerte, y en el marco del Estado Constitucional ya operante, a la actuación de los poderes creados y ordenados por el Poder Constituyente en la propia Constitución. Poderes constituidos éstos que, como mecanismo para hacer efectiva la libertad civil consagrada en las Declaraciones de Derechos (P. De Vega), y como un instituto inseparable e indisoluble de éstas (H. Heller), se entendió ya desde los primeros procesos revolucionarios liberal-burgueses de finales del siglo XVIII, y hasta nuestros días, debían ser organizados de acuerdo con la teoría de la división de poderes debida al ingenio del barón de La Brede y de Montesquieu, es decir, dividiéndolos en Poder Legislativo, Poder Ejecutivo y Poder Judicial.

No es éste, obviamente, el momento oportuno para detenernos a realizar una exposición exhaustiva y pormenorizada de la doctrina de Charles-Louis de Secondat, el modo en que su construcción fue recogida por los distintos Constituyentes - dando origen a la distinción entre el sistema de gobierno presidencialista y el sistema parlamentario-, y la evolución que este principio ha tenido en la práctica política, y sobre todo con el tránsito de aquel viejo Estado Constitucional liberal, construido sobre la falaz contraposición fisiocrática entre Estado y Sociedad, al Estado Constitucional democrático y social, en el que, por un lado, se generaliza la democracia representativa en régimen de partidos, produciéndose, con ello, la transformación del sistema de pesos y contrapesos ideado por el noble francés en el diálogo y oposición de los partidos de la mayoría y de la minoría, y en el que, por otro, y como entidad única que es, al poder político se le oponen los poderes privados. Aunque, sin embargo, y en la medida en que enlaza de manera directa con el problema que ahora nos ocupa, y servirá para facilitar la comprensión de nuestro discurso, no está de más recordar que, al dividir el poder del Estado, que es un poder constituido, en Legislativo, Ejecutivo y Judicial, lo que Montesquieu pretendía era asegurar al ciudadano el 
disfrute del mayor grado posible de libertad mediante un sistema de equilibrio político en el que «el poder frene al poder», en el sentido de que, en este contexto, «los tres poderes permanecerán así en reposo o inacción, pero como por el movimiento necesario de las cosas, están obligados a moverse, se verán forzados a hacerlo de común acuerdo».

Lo que, en realidad, nos interesa aquí es que, desde los esquemas conceptuales puestos en marcha por Montesquieu, desde los que el constitucionalismo se configura, ante todo y sobre todo, como un gran sistema de garantía de la libertad individual frente al gobernante, resulta inherente al propio concepto del Estado Constitucional el que, en él, el poder político ha de estar dividido, y, además, en un doble plano. En primer lugar, es menester que aparezca la distinción, previa e, incluso tácita, entre poder soberano y poderes no soberanos, que ha de mantenerse, además, a lo largo de toda la vida de la Comunidad Política, al menos en condiciones de normalidad. Hace, de este modo, su entrada en escena la oposición Poder Constituyente, como poder absoluto, soberano e ilimitado en el contenido, formal y material, de su voluntad, y poderes constituidos, cuya actuación se realiza en el marco de la voluntad del primero. Distinción ésta cuya paternidad remota, como, con meridiana claridad, han puesto de manifiesto Zweig, Carré y De Vega, no ha de buscarse, como usualmente se hace, en las formulaciones de Rousseau sino, por el contrario, en las de Montesquieu. Y ello por cuanto que, como escribe el Maestro De Vega, la noción de Pouvoir Constituant «constituye una premisa lógica y perfectamente presumible en la lógica global de su pensamiento, en la medida en que la aparición de los tres poderes [...], que recíprocamente se vigilan y controlan como poderes constituidos, no se concebiría sin el reconocimiento de un poder previo y superior en el que aquellos cifrarán la razón de su existencia». Es, asimismo, y en segundo término, preciso que, establecido el poder no soberano del Estado, su ejercicio no quede en manos de un único sujeto, lo que, de manera inevitable, conduciría a que éste cometiera abusos en detrimento de la libertad de los ciudadanos.

Este es el esquema que, como observó/denunció Heller, no admitían los totalitarismos del período entre guerras, y el que, en consecuencia, tratarían todos ellos de destruir, y, de una manera muy concreta, lo haría Mussolini. El mecanismo para eliminar la vigencia del principio de división de poderes radicaba, de una manera básica y fundamental, en la substitución del régimen pluripartidista por el de partido único, en el que, como señala el jurista y politólogo alemán, la organización partidista al servicio del dictador es elevada a la condición de aparato del Estado.

En tales circunstancias, la eliminación del sistema de frenos y contrafrenos diseñado por Montesquieu entre el Ejecutivo y el Legislativo resulta evidente, y, 
entendemos, a nadie puede ocultársele. Tanto más si se toma en consideración el sistema que el dictador italiano puso en marcha para reclutar a los miembros del Parlamento. En efecto, señalaba Heller a este respecto que «Actualmente, el Senado y la Cámara de los Diputados son instrumentos ciegos de la dictadura. Lo demuestra la forma de su nombramiento, puesto que, en realidad, los miembros de ambas Cámaras son nombrados por el dictador. Cierto es que en el Senado quedan todavía un gran número de senadores vitalicios de los tiempos prefascistas, una parte de los cuales, a pesar de la presión dictatorial y de las amenazas personales, se atreven todavía a levantar su voz contra el dictador. [...]. Pero el Senado, que por el modo de su nombramiento tenía que ser grato a Mussolini y nunca podía llegar a ser peligroso, estaba ya reducido por la Constitución albertina a un papel secundario en la formación de la voluntad política, correspondiendo el papel decisivo a la Cámara de los Diputados, designada por elección. Pero a partir de la ley de 17 de mayo de 1928, la Cámara de los Diputados no se elige ya por el pueblo, sino por el Gran Consejo [Fascista, designado en su mayoría por el dictador], es decir, en fin de cuentas, por el mismo Mussolini».

No podría, desde luego, Heller dejar de pensar que este modelo, o alguno similar, sería adoptado en Alemania por Hitler. Dada la admiración que este último sentía, como ya hemos dicho, por el gobernante fascista, podía muy bien nuestro autor imaginar que también en su patria estaría condenado el principio de división de poderes en lo que hace a las relaciones entre el Legislativo y el Ejecutivo. Sería, a nuestro juicio, también posible estimar que Heller podría considerar que el gobernante nacional-socialista podría incluso agravar lo hecho por Mussolini. Y así, en efecto, lo haría. Aunque Heller no llegase a vivir lo suficiente como para conocer en toda su intensidad la política hitleriana en este punto, podía muy bien imaginárselo. $\mathrm{Y}$, en este sentido, nos encontramos con que si, a nivel jurídico y formal, el Duce mantuvo la existencia del Parlamento, aunque totalmente desvirtuado en su esencia, Hitler, mucho más expeditivo, se libraría de este último, procediendo a su clausura.

Lo mismo sucedería con el Poder Judicial. En este supuesto, la eliminación del dogma de la magistratura como un poder independiente tanto del Parlamento como del Gobierno puede parecer inexistente. Sin embargo, aquella eliminación existe. La misma no depende, o al menos no exclusivamente, de la falta de profesionalidad por parte de jueces y magistrados, sino de las circunstancias en las que han de ejercer en el marco de los regimenes totalitarios. De manera fundamental, de la existencia del régimen de partido único. Heller lo pondría claramente de manifiesto en relación con la Italia fascista. Aunque la cita es larga, resulta realmente oportuno el transcribirla. Señala nuestro autor a este res- 
pecto que «La concentración descrita del Poder ejecutivo y legislativo en las manos del dictador da también al traste con la independencia que el Poder judicial tiene en el Estado de derecho. La independencia de los jueces es sólo un corolario de su dependencia de la ley, [...] En el sistema del Estado de derecho la garantía de justicia relativa de la ley estriba en todo el procedimiento legislativo, a través del cual deben expresarse y completarse, con la mayor libertad e igualdad posibles, todas las valoraciones que viven en el pueblo. [...] Cuando el dictador concentra en sus manos el Poder legislativo y cuando todas las normas jurídicas superiores emanan más o menos exclusivamente de su voluntad, el juez no depende ya de las leyes, sino de la voluntad actual del dictador y, por tanto, la administración de justicia es también dictatorial».

Y si esto es así respecto de la llamada "parte orgánica» de la Constitución, es menester indicar que a este proceso de destrucción del Estado Constitucional iniciado por el totalitarismo fascista tampoco podría escapar la que, de algún modo, y desde la entrada en vigor de los Textos mexicano de 1917 y alemán de 1919, — los primeros de esa nueva manifestación estructural de la Comunidad Política que, como escribió Heller, se caracteriza, ante todo y sobre todo, por ser el resultado de una situación coyuntural que da origen a «una época en la que los antiguos ideales de forma política ya no sirven y los nuevos carecen de validez. [... De suerte tal que], el Estado liberal de derecho ya no es capaz de hacer frente a las tareas del presente, pero la forma política de un Estado social de derecho está sólo en gestación", y, en cualquier caso, los primeros que, por nacer con la aceptación incondicionada del dogma político de la soberanía popular, hacen depender la eficacia de la libertad civil del principio democrático-, se configuraba no como la "parte dogmática», como sucedía en el Estado Constitucional liberal, sino, y por decirlo en palabras de Jiménez de Asúa, como la "parte sustantiva» de la Constitución. A tal fin, resultaba especialmente útil a los dictadores fascistas la concepción de la Verfassungswandlung mantenida por el primer positivismo jurídico formalista, y de modo particular por Laband y Jellinek. Ocurre, no obstante, que no fue ésta la única contribución del positivismo jurídico formalista a la eliminación fáctica de los derechos fundamentales por parte de los totalitarismos.

En este sentido, debemos a Smend una observación fundamental al respecto. Los problemas relativos a la falta de una verdadera eficacia de las normas constitucionales declarativas de derechos en Weimar no se derivaban tanto de las propias prescripciones de la Constitución, o de que el Legislador Constituyente de 1919 no hubiese establecido un recurso jurisdiccional específico que permitiera al ciudadano reaccionar ante la violación de sus derechos, — lo que, como, desde la observación de la realidad jurídico-política estadounidense, puso de ma- 
nifiesto el propio Kelsen, si bien resulta muy útil para el adecuado desenvolvimiento de la proyección normativa de aquellas normas, no resulta, en cambio, decisivo- , cuanto de la interpretación que de las mismas hacía el positivismo jurídico formalista en su condición de grupo académico mayoritario del momento. Se verificaba, en este punto, una de las más patentes paradojas de la República de Weimar, a la que, no obstante su capital importancia y trascendencia, se le ha prestado una escasa atención, por lo menos entre los iuspublicistas españoles, y sobre la que conviene decir algo.

Ha de tomarse en consideración, en primer lugar, que, porque a raíz de la Revolución alemana, y como consecuencia directa e inmediata del aceptación del principio democrático como único criterio legitimador, vertebrador y fundamentador de la Comunidad Política, surge la idea, siquiera sea desde el punto de vista teórico, de que, de un modo muy diferente a lo que sucedía en el Estado Constitucional liberal, los derechos fundamentales valen en la medida en que son incorporados por la voluntad soberana del Pouvoir Constituant a la Constitución, fue ya en el período entre guerras donde surgió la idea de que las normas constitucionales declarativas de derechos, que forman parte de un cuerpo normativo que es una autentica norma jurídica, gozan de una verdadera fuerza jurídica obligatoria y vinculante. Tesis ésta que, huelga decirlo, sería, como otros muchos conceptos surgidos entonces, aceptada y desarrollada por la dogmática constitucional después de la II Guerra Mundial (C. Ollero, P. De Vega, etc.), y que, en definitiva, y como está generalmente aceptado, constituye uno de los mejores aciertos, y más grandes contribuciones, de la llamada Teoría Constitucional de Weimar. Ahora bien, si esto es así, ocurre que lo que muy pocas veces se dice es que, tratando, justamente, de dotar de una eficacia total y absoluta a los derechos fundamentales $y$, al mismo tiempo, siendo conscientes de que la libertad civil de los ciudadanos podía ser conculcada un tanto por el poder público como por el poder privado, fue ya en los tiempos de la República de Weimar donde, como recuerda el Maestro De Vega, se formularían las bases teóricas sobre las que, en un momento posterior, se llevaría a cabo la conceptualización de la Drittwirkung der Grundrechte. Instituto éste que se basa en la idea de que, en tanto en cuanto los derechos y libertades de los ciudadanos pueden ser conculcados tanto por los poderes públicos como por una serie de entes que, siendo formalmente sujetos de Derecho Privado, rompen las reglas del principio de la autonomía de la voluntad y actúan en situación de imperio respecto a los particulares individualmente considerados, ha de ser misión prioritaria del ordenamiento jurídico establecer la garantía de los derechos no sólo frente a los actos del Estado, sino también, y, aunque con ciertos límites, con la misma intensidad, respecto de los actos de los poderes privados. 
Frente a esta genial intuición, no puede olvidarse, en segundo término, que durante la vida de la República de Weimar la problemática de la libertad civil se caracterizaría, como decíamos, por la escandalosa falta de eficacia jurídica de las normas constitucionales declarativas de derechos. Lo que, en última instancia, se debió al hecho de que el positivismo jurídico formalista seguía aferrado a la idea de que la eficacia jurídica de los derechos y libertades no dependía de que éstos estuvieran consignados en la Ley Constitucional, sino, muy al contrario, de que los mismos fuesen regulados y desarrollados por el Legislador ordinario. Como he mantenido en otro lugar, nos encontramos ante una palmaria incongruencia. A saber: que, siendo como es, y de manera incuestionable incluso para la más radical de las concepciones formalistas de la Constitución, que es la que remite, de modo exclusivo, al artículo 16 de la Declaración de Derechos del Hombre y del Ciudadano de 1789, la libertad civil un componente necesario e inseparable del propio concepto de los Códigos Jurídico-Político Fundamentales, y que, por ello mismo, no puede ser concebida lógicamente más que como Derecho Constitucional, el positivismo jurídico formalista radical la reduce a ser un contenido del que, con Smend, podemos llamar «Derecho técnico especial» (D. Administrativo y D. Civil, singularmente).

De cualquier forma, lo que realmente nos interesa aquí es indicar que, como muy bien indicó Heller, apoyándose en las concepciones del viejo positivismo jurídico formalista, y que eran mantenidas vivas por los nuevos cultivadores de este método, resultó muy fácil a los totalitarismos fascistas proceder a la aniquilación total de la libertad civil. Empezando por el que es, sin discusión alguna, y desde la aceptación de la idea de John Wise de que la libertad civil (derechos fundamentales) es aquella parte de la libertad natural (derechos humanos) que corresponde a los individuos en su condición de ciudadanos de una determinada y concreta Comunidad Política, y que es ésta la única que puede hacerse valer frente al Estado, el primero de los derechos políticos: el derecho de ciudadanía. Tal era, en efecto, la sanción máxima establecida en el artículo 5. ${ }^{\circ}$ de la Ley para la Defensa del Estado, aprobada por Mussolini en su Parlamento el 25 de noviembre de 1926. En su virtud, fueron muchos los italianos a los que se les privó de la ciudadanía por parte del Tribunal militar excepcional. Pero no fue ésta la única medida normativa de la que se sirvió el dictador italiano. En efecto, y como señala Heller, no dudaría el Duce en recurrir al Decreto para arrebatar la ciudadanía, por ejemplo, a Gaetano Salvemini, insigne historiador de la Universidad de Florencia, admirado profundamente incluso por los propios historiadores fascistas. Y si esto era así en Italia, algo parecido cabría esperar, y Heller no podía ignorarlo, de una Alemania gobernada por el nacional-socialismo. 
La misma suerte correrían el resto de los llamados «derechos políticos y de participación». Éstos serían, obviamente, y entendiéndolos en su manifestación realmente democrática, eliminados por ser incompatibles con el régimen. Lo que, en nuestra modesta opinión, a nadie puede, ni debe, sorprender. Hay que tener en cuenta que, en último extremo, el derecho de sufragio libre y democrático, así como el resto de los derechos de participación en los asuntos públicos, no son más que la derivación natural del dogma político de la soberanía del Pueblo, en el entendimiento de que, como ha escrito De Vega, uno de los principales corolarios del principio democrático es el de que «el pueblo que estatuye y sanciona la Constitución, lo que no puede hacer, una vez establecida la normativa fundamental, es quedar marginado del proceso político». Siendo así, nada de extraño tiene que siendo el totalitarismo fascista una ideología radical y definitivamente contraria a la teoría de la soberanía del Pueblo, para cuya destrucción encontraba un magnífico arsenal en la dogmática positivista alemana del Derecho Público, y que sentía un desprecio sin límite hacia la participación popular en la Res Publica,- - lo que le haría acudir a la concepción del elitismo político para la articulación de su farsas electorales_-, tratase de eliminar cualquier participación política democrática por parte de unos ciudadanos a los que, en realidad, y como ya hemos visto, no reconocía tal condición.

En el mismo orden de cosas, tampoco mantendrían su vigencia y eficacia reales los derechos vinculados a la llamada «libertad personal». El Duce, como lo harían el resto de los dictadores fascistas, incluido Hitler, utilizaría el Derecho ordinario, en concreto la Ley de Policía de Seguridad de 26 de noviembre de 1926, para abolir de facto «todas las instituciones que en el Estado de Derecho están destinadas a proteger la libertad personal. No existe ni inviolabilidad de la correspondencia, ni de domicilio, ni de protección contra las detenciones arbitrarias» (Heller).

Importa señalar que, en este proceso de destrucción de la libertad civil, no tuvo el totalitarismo fascista ningún límite. Llegando, incluso, a la abolición de aquello que para Heller, que, si se me permite la simplificación, era un gran fichtiano, había de constituir uno de los pilares fundamentales de la Comunidad Política democrática. Nos referimos, claro está, a la libertad de pensamiento y a todas aquellas otras que sirven para materialización de ésta: libertad de expresión, de prensa, de ciencia, etc. Para comprender la importancia que Heller, tanto como ciudadano demócrata individualmente considerado, como en su condición del teórico y práctico de la política, otorga a la violación de estos derechos, — de la que, como veremos, llegó a ser víctima por parte del nacional-socialismo-, resulta conveniente situar este problema en los esquemas conceptuales trazados por quien, de uno u otro modo, constituye su fuente de inspiración. No 
referimos, obviamente, a aquel Fichte que, en 1793, y en defensa de su muy admirado Immanuel Kant, reivindica a los príncipes la libertad de pensamiento en todas y cada una de sus manifestaciones.

En este sentido, es menester recordar que, partiendo, bajo la influencia de Rousseau y Kant, de la doctrina del contrato social, concibió Fichte la Comunidad Política como una obra humana cuya creación, y esto es lo importante, requiere que todos los futuros ciudadanos estén dispuestos a la renuncia de una parte de su libertad para, justamente, hacer posible la eficacia de los derechos fundamentales. El filósofo de Rammenau lo explicaría en los siguientes términos: "Puedo renunciar a mis derechos alienables sin condición alguna, puedo donarlos a otros, también puedo renunciar con condiciones, puedo cambiarlos por alienaciones que otros hacen de sus propios derechos. Yo renuncio al ejercicio de uno de mis derechos con la condición de que otro renuncie al ejercicio de los suyos. [...] La sociedad civil se funda en un contrato de este género, [...], y no puede fundarse en otra cosa, porque es absolutamente ilegítimo dejarse dar leyes por otro. La legislación civil en es válida para mí solo en tanto la acepto voluntariamente [...] y me doy a mí mismo la ley. [...]. En este contrato social cada miembro renuncia a algunos de sus derechos alienables a condición de que los otros renuncien también a alguno de los suyos. [...] Si un miembro no cumple su compromiso adquirido por el contrato y recupera los derechos que había alienado, entonces la sociedad tiene el derecho a forzarlo a cumplir mediante la restricción de los derechos que le garantiza su permanencia la misma».

De las sentencias anteriores se deriva, y, creemos, que no existirá dificultad alguna para aceptarlo, que Fichte admitía dos tipos de derechos. Por un lado, estarían los derechos alienables, que «sólo pueden ser derechos a acciones externas [permitidas por la ley] y no a convicciones interiores", que pueden ser, de manera absolutamente voluntaria, renunciables y que, en cuyo caso, su ejercicio, en cuanto que contrario al pacto social establecido, podría ser reprimido por el Poder Ejecutivo. Por otro, estarían los derechos inalienables, que se concretan en el ámbito de la libertad y la personalidad, y cuya principal característica que es la de que si el ciudadano, ni siquiera de forma voluntaria, puede hacer renuncia de los mismos, el Poder Ejecutivo, es decir, el poder político en toda su extensión, no podrá nunca proceder a su restricción o eliminación. Entre estos últimos, y, en la medida en que «Poder pensar libremente es la diferencia distintiva entre el entendimiento humano y el animal» (Fichte), ocuparía un papel central la libertad de pensamiento. Entiende por ésta Fichte no sólo que el que el poder político no prohíba al ciudadano que piense libremente, — que, como es evidente, y porque sería imposible impedirlo, y esto es así incluso en aquellos Estados que, 
por articularse en torno a una fe religiosa, tratan de limitar la libertad de creencia o culto- , sino el que pueda comunicarse, también de manera absolutamente libre, el pensamiento. Lo que, traducido en otros términos, significa que la libertad de pensamiento se convierte, para ser plena y real, en el derecho bilateral de libre comunicación, el cual, necesaria e ineludiblemente, comprende la libertad de expresión, de prensa y de investigación.

No es menester entretenerse mucho tiempo en demostrar que el pensamiento fichtiano sobre este particular sería, como seguramente no podría ser de otro modo, totalmente asumido por todas las corrientes democráticas que existen en el ámbito de la confrontación política partidista. Aunque no está de más recordar que, en el mismo momento histórico en que Heller criticaba y denunciaba la situación en la Italia de Mussolini, los demócratas españoles hacían lo mismo respecto de la dictadura de Alfonso XIII/Primo de Rivera. Ahí está, por ejemplo, la defensa que, desde las páginas de "España», y con unas, a nuestro juicio, más que evidente resonancias fichtianas, realizó Azaña de la libertad de escribir tan sólo nueve días después de haberse perpetrado el golpe monárquico-totalitario, o sus continuas denuncias de la censura, entendiéndola, y con razón, como uno de los principales instrumentos con los que contaba la dictadura para impedir que pudiera hacerse pública la existencia de la discrepancia política. Criterio éste al que, dígase hoy lo que se diga, se mantendría fiel el alcalaíno durante su mandato como Presidente del Consejo de Ministros. Y ello, por la sencillísima razón de que la Ley de Defensa de la República —instrumento jurídico robespierriano donde los haya, y que, de una u otra forma, y sin el menor esfuerzo, es posible relacionar con aquélla defensa político-existencial y total de la Constitución y, en definitiva, del régimen político puesta en marcha por el jacobinismo revolucionario radical de izquierda—, así como otros cuerpos normativos más concretos $(v . g r$., sobre la supresión de la prensa militar), no tenían, como de manera reiterada señaló en las Cortes Constituyentes el propio Azaña, por misión establecer límites en el ejercicio de la libertad expresión a las oposiciones parlamentarias, fuesen éstas republicanas o no republicanas, a la prensa, o, más en general, a cualquier ciudadano español. Por el contrario, su finalidad era la de actuar como medio de defensa de la revolución del 14 de abril, tanto tratando de evitar que los que Robespierre denominó «malos ciudadanos» llevasen a cabo actos de agresión a la República, como sancionando a quienes efectivamente los perpetrasen.

De cualquier modo, lo que nos interesa aquí, es que Heller conocía perfectamente que no mejor suerte que la que habían tenido en la Italia fascista, habrían de correr los derechos fundamentales en una Alemania gobernada por Hitler. Siendo así, es seguro que no le sorprendió verse, él mismo, como sujeto 
paciente de la conculcación de la libertad del pensamiento, a la que, por lo demás, siempre han sido tan aficionados los partidarios del totalitarismo.

Que Heller tenía motivos para sospechar que el ascenso al poder de Hitler iba a suponer la efectiva derogación de la Constitución de 1919, es lo que hemos tratado de poner de manifiesto en lo hasta aquí dicho. Que tales sospechas fueran las que le condujeron a exiliarse, y que su decisión hubiera sido la misma incluso sin que sus amigos le hubiesen comunicado sus temores, no es, lo reconozco, más que una simple especulación, aunque, en mi opinión, resulta plausible. Sin embargo, lo que no es una mera disquisición, sino una auténtica realidad es que el nacional-socialismo, sin quebranto alguno de la legalidad, aunque sí, y de manera incuestionable, de la legitimidad, decretó la desaparición definitiva del ordenamiento constitucional weimariano. Éste era, en efecto, el contenido real de aquellas leyes que el Führer hizo aprobar al Parlamento el 24 de marzo de 1933 y el 31 de enero de 1934. Tampoco es un mero juego de la inteligencia - destinado a esa teorización por la teorización que, de acuerdo con Heller, queda excluido del quehacer del estudioso del Estado, el Derecho y la Política, al menos si éste es consciente de su responsabilidad intelectual y social-, el que este proceso de destrucción del régimen inaugurado con el Texto de Weimar recibió el visto bueno de no pocos de los autores del positivismo jurídico formalista, cuyas construcciones dogmáticas, ajenas a aquel principio de legitimidad democrática al que, ya en 1931, Heller se negaba a prescindir y renunciar, otorgaban la condición de Derecho Positivo, y, en consecuencia, válido, obligatorio y vinculante, a cualquier norma que respetara formalmente la legalidad, cualquiera que fuese su objeto.

\section{2.- La Ley de plenos poderes y su significado como justificación de la marcha al exilio}

Si la, de modo más que lamentable, inevitable derogación fáctica de la Constitución de 11 de agosto de 1919 era un motivo más que suficiente para la opción por el exilio por quien estaba política y doctrinalmente tan comprometido con aquélla como lo estaba Hermann Heller, creemos que, sin embargo, no fue ésta la única circunstancia que, desde un análisis objetivo y general de la situación, le condujo a adoptar su decisión. Junto a ella, y con la misma intensidad, resulta perfectamente imaginable el que en el ánimo de nuestro autor pesara la aprobación de la Ley por la que se otorgaban a Hitler plenos poderes. El significado político y jurídico real de esta norma, no podía ser desconocido por Heller, y, en el mismo orden de ideas, no podría éste dejar de tomarlo en consideración. Veámoslo, siquiera sea brevemente. 
En su estudio/denuncia sobre el fascismo italiano, había puesto de relieve Heller cómo, en el proceso de renovación fascista de los contenidos políticos, el totalitarismo de derechas había mostrado una especial aversión al dogma político de que el Pueblo, y sólo el Pueblo, es el único sujeto legitimado para decidir los modos y las formas en que va a ser gobernado y que, en consecuencia, - $-\mathrm{y}$ como, de algún modo, había sido ya sentado por el Maquiavelo teórico del Estado en situación de normalidad-, el único dueño de su destino. Su intención, como ha de ser para todos meridiano, era la de sustituir la soberanía del Pueblo por la soberanía del dictador.

Para lograr el éxito en esta empresa, el fascismo italiano, merced a su proverbial falta de convicciones políticas - que quedaba incuestionablemente demostrado en aquélla proclama de Mussolini, conforme a la cual «Nosotros [los fascistas] nos permitimos el lujo de ser aristocráticos y democráticos, conservadores y progresistas, reaccionarios y revolucionarios, legalistas e ilegalistas según las circunstancias del tiempo, de lugar, de ambiente en que nos vemos obligados a vivir y a obrar», a lo que, con un especial interés para lo que ahora interesa, habría que añadir la grandísima habilidad demostrada por el totalitarismo fascista para, de igual manera que venía haciéndolo el conservadurismo antidemocrático europeo desde el comienzo del siglo XX ( $v$. gr. la Action française en el marco de la III República), presentarse al mismo tiempo como anticlericales/no creyentes y católicos-, no dudaría en acudir al criterio irracional de la legitimación carismática del poder. Y, en ello, tendrían, al menos aparentemente, un triunfo. Piénsese que, como advirtió Heller, todavía en 1928 «Es también cierto, aunque no hasta el extremo que se cree en el extranjero, que para muchos italianos la dictadura se legitima como un don divino, gracias a los atributos que adornan al dictador». Lo que se explica, y únicamente puede hacerse así, por el hecho de que Mussolini, al igual que los dictadores españoles del siglo XX, gozarían de un muy fuerte - $\mathrm{y}$, al mismo tiempo, muy poco cristiano- apoyo por parte de la jerarquía vaticana.

Ahora bien, consciente el totalitarismo fascista de la endeblez de este criterio de legitimación, que se hacía tanto más evidente cuanto que muchos de los gobernantes fascistas veían en la alianza con la Iglesia católica tan sólo un arma coyuntural para la conquista y/o el mantenimiento del poder, pusieron a sus teóricos e ideólogos a buscar otros argumentos con los que justificar, política y jurídicamente, la conversión del dictador en el único, y auténtico, titular de la soberanía en el Estado. Y estos juristas y politólogos al servicio del Duce encontraron, como dice Heller, en el marco del Derecho Constitucional monárquico elaborado por el primer positivismo jurídico formalista alemán el arsenal conceptual adecuado para su fin. 
La razón de que esto fuese así, no ha de ser muy difícil de comprender, ni de compartir. Recuérdese, a este respecto, que, como ya quedó, de una u otra forma, apuntado, procedió el monarquismo - representado de un modo básico y fundamental en la academia por la Escuela Alemana de Derecho Público, pero no sólo por ella, y que en el ámbito de la política práctica había encontrado, al decir de Heller, su representante más influyente en Treitschke- a la eliminación total, absoluta y definitiva del dogma de la soberanía popular, y a la consagración de la soberanía del Estado, sin otra finalidad política que la de erigir al Kaiser Guillermo, y no tanto en su condición de Emperador cuanto en la de rey de Prusia, en la posición de sujeto legibus solutus en el ámbito de un Estado que, sin embargo, ya no se correspondía con los esquemas del Antiguo Régimen y, además, contaba con una Constitución. La manera de hacerlo no pudo ser, en verdad, más simple. En efecto, para lograr sus fines partió la Escuela Alemana de Derecho Público, y, con ella, todo el positivismo jurídico formalista que operaba con el principio monárquico, de las especulaciones hegelianas sobre la soberanía del Estado. Tesis ésta que aceptarían como válida, si bien la interpretaban no desde las propias concepciones de Hegel — que, como ya hemos dicho, aceptaba la idea de que el Pueblo es el titular de la soberanía, y trataba de salvar esta titularidad compatibilizándola con las pretensiones del monarca-, sino, por el contrario, a la luz de aquel "Autoridad, no mayoría» acuñado por Stahl. De esta suerte, y desde la afirmación, aceptada en términos generales por todos los defensores de la forma de Gobierno monárquica, de la creencia de que «el monarca era anterior y superior a la Constitución» (Heller), no hallarían obstáculo alguno el positivismo jurídico formalista para configurar al rey como el titular o, al menos, único depositario posible y legítimo de la soberanía del Estado. Lo que harían o bien, y como era el criterio mayoritario entre los juristas del momento (p. ej., von Seydel, Bornhak, Le Fur, ...), de un modo directo, con la identificación del Jefe del Estado con el propio Estado, o bien, y como hacía Jellinek, quien, oponiéndose expresamente a esta identificación y a esta atribución, de manera indirecta al considerar al monarca como el único representante legítimo del Estado, y que, como representante del Estado soberano, se acaba convirtiendo, él mismo, en el soberano.

No hace al caso detenernos, aquí, a advertir que no le faltaba la razón a Heller cuando indicaba que, aunque con una innegable e incuestionable efectividad en el campo de la política práctica, lo cierto es que la apelación y aplicación estricta de todo este aparato conceptual del monarquismo alemán presentaba, empero, no pocas dificultades desde el punto de vista de la lógica teórica. Y ello, por cuanto que, como escribió el muy brillante constitucionalista y politólogo alemán, al haberse puesto en marcha el sistema totalitario sin haber cambiado la 
forma de Gobierno, lo que sucedía en la Italia fascista es que la titularidad jurídico-formal de la soberanía no habría de corresponder al dictador, que la detentaba tácticamente, sino al monarca.

Tampoco reviste una singular importancia, a los efectos del presente escrito, remarcar que, en este sentido, tuvieron una mejor fortuna las dictaduras españolas del siglo XX. La primera, porque establecido el régimen totalitario, y mientras éste duró, Alfonso XIII, que, de acuerdo con lo que establecía la Constitución de 1876, era ya cotitular de la soberanía desde el punto de vista formal, y que materialmente, y en lógica coherencia con los presupuestos políticos reales del constitucionalismo del liberalismo doctrinario, lo era en realidad en exclusiva, seguiría siendo el soberano. La segunda, porque el gene$\mathrm{ral} /$ dictador ferrolano, de una manera mucho más hábil que Mussolini, había conseguido solventar la dificultad con la que este último se encontró al reservarse el papel de Jefe del Estado en calidad de regente de la nueva monarquía absoluta española.

Lo que nos interesa, es poner de manifiesto que el nacional-socialismo alemán demostraba una idéntica enemiga a la soberanía del Pueblo, y que, de igual manera que Mussolini, su líder aspiraba a convertirse en el soberano. E importa, a este respecto, advertir que en esta pretensión Hitler no sólo iba a encontrar el apoyo y el respaldo teórico de los autores adscritos al positivismo formalista que continuaban defendiendo la lógica jurídica y política derivada del principio monárquico. Junto a ellos, y actuando asimismo, y como con gran acierto, aunque no sin gran dosis de hipocresía, había denunciado Kelsen, con este mismo principio, contribuirían a la configuración del dictador como soberano todos los juristas y politólogos antidemócratas, y de un modo muy particular los del positivismo sociológico decisionista.

Heller, en marzo de 1933, era bien consciente de esta circunstancia. En efecto, hacía ya varios años que Heller, como académico, había tenido ocasión de polemizar con el que, con toda probabilidad, era el más brillante de los constitucionalistas antidemócratas alemanes, y, en todo caso, uno de los más fervientes defensores del totalitarismo nacional-socialista: Schmitt. Su debate, que se llevaba a cabo sobre el verdadero significado del artículo 48 de la Constitución de 1919, la llamada «cláusula dictatorial», y su relación con la soberanía, merece la pena ser recordado.

En este sentido, es menester recordar que para Schmitt, la utilización del artículo 48 del Texto de Weimar comporta, de algún modo, la traslación fáctica de las facultades absolutas inherentes al soberano al Presidente del Reich, el cual, en tanto en cuanto decide en última instancia mientras dura la suspensión constitucional, se convierte, siquiera sea temporalmente, en el verdadero titular de la 
soberanía en el Estado. Ahora bien, Schmitt, siempre desde el principio monárquico que le sirve de apoyatura conceptual, opina que la solución adoptada por el Legislador Constituyente alemán de 1919 no es la más correcta y adecuada. Antes al contrario, ésta, en opinión del jurista totalitarista, se encuentra viciada por las muchas contradicciones que contiene la regulación legal-constitucional y que, para él, -y entrando ya, y como tanto le gustaba hacer, en el terreno de la crítica transcendente-, son fácilmente comprensibles. Dirá, de esta suerte, Schmitt que las «contradicciones de la Constitución alemana de 1919 no son extrañas, ya que son el resultado de la combinación de una dictadura soberana con una dictadura comisorial, cuyo desarrollo corresponde totalmente al embrollo sin salida en que se ha metido». Contradicciones éstas que, en última instancia, se concretan en que mientras que en el Estado absoluto «el rey absorbía la soberanía, en el sentido de una plenitud de poderes extraordinaria e ilimitada, [...], ahora el presidente del Reich, o bien el parlamento, debido al control que ejerce sobre el presidente del Reich, domina el estado de excepción ilimitado. Con ello, el presidente, o el Reichstag, se convertiría en portador de un pouvoir constituant y la Constitución permanecería como un precario orden provisional, formando parte del orden constituido. El presidente del Reich podría asumir semejantes facultades sobre la base de una delegación de la Asamblea Nacional constituyente, si se consideraba a ésta como portadora del pouvoir constituant y al presidente como comisario suyo. [...]. La consecuencia sería, [...], que esta delegación cesaría también al cesar la Asamblea Nacional. En cambio, el Reichstag, en cuanto pouvoir constitué, no estaría evidentemente nunca en situación de conferir tales comisiones ilimitadas».

No obstante la crítica anterior, Schmitt no duda en utilizar el artículo 48 del Texto weimariano como un instrumento para justificar la futura dictadura nacional-socialista. Esto era realmente lo que le interesaba, y a lo que, como es por todos conocido, dedicó su ingenio en toda, o casi toda, su obra anterior a la Segunda Guerra Mundial. Y lo hará, de cualquier forma, sin olvidar esa obsesión de los partidarios de los totalitarismos por presentar sus propuestas no sólo como democráticas, sino como las más democráticas posibles y las únicas viables. En este caso, y porque actúa en el marco de la República alemana de 1919, lo que le servirá de cuartada es el modelo de elección del Presidente diseñado por el artículo 41 del Código Jurídico-Político Fundamental de Weimar. En efecto, partiendo de que este precepto establece que el Jefe del Estado sería elegido entre todos los alemanes que hayan cumplido los 35 años y por todo el Pueblo alemán, Schmitt, con el ingenio y la habilidad que siempre le caracterizaron, forzará el sentido de esa elección directa del Presidente, y ello para convertirle, según el propio principio democrático, en el depositario de la soberanía desde el 
entendimiento de que sus actos son una verdadera, e innegable, «apelación al Pueblo». Porque esta es su interpretación del régimen constitucional alemán de 1919 en condiciones de normalidad, a nadie puede, o, al menos, no debería, extrañar las consecuencias que extrae para las situaciones de excepción. Para Schmitt, lo que, en rigor, hace el artículo 48 es convertir al Jefe del Estado en el auténtico, si no en el único, depositario de la soberanía. De ahí deducirá que, justamente por su condición de soberano, el Presidente del Reich se configura como el mejor y el natural «Der Hüter der Verfassung».

No resulta ocioso, — sobre todo tomando en consideración que han sido no pocos los prácticos de la política y comentaristas y analistas de la vida pública los que han apelado una posible intervención directa del monarca para dar respuesta «adecuada» a la situación generada en la España de 1978 a partir de 2003 y con la apertura de lo que se ha dado en llamar el segundo proceso de descentralización- recordar que éstas concepciones schmittianas trataron de ser utilizadas durante la Segunda República. Pese a que, de manera intencionada y, entre otras cosas, para soslayar los problemas operativos que se habían puesto de manifiesto en la República de Weimar, el Constituyente español de 1931 había cerrado la puerta a la interpretación de que el Presidente de la República era el soberano y el natural defensor de la Constitución, es lo cierto, sin embargo, que a esa condición apelaron, y no por casualidad, las derechas no republicanas en el momento de la obstrucción parlamentaria al Gobierno republicano-socialista presidido por Azaña, y continuaron haciéndolo en los primeros días del «Bienio Negro». E interesa recordar que fue el propio Azaña quien, desde posicionamientos teóricos e ideológicos compatibles con el sistema democrático-parlamentario diseñado por el Pouvoir Constituant originario, se encargaría de negar la posible aplicación de las tesis de Schmitt en la España republicana. Sus palabras, que de modo directo e inmediato enlazan con la tesis jacobina de la «Nación en armas», son bien claras y contundentes: «No me gusta oír lo que decía hace pocas semanas un respetabilísimo miembro del Gobierno actual. [...]: «! Ah!; pero, en último término, el Jefe del Estado es una garantía para la República». [...]. Y yo digo: evidentemente, dentro del Régimen, de la Constitución, todos los Poderes tienen que ser garantía de la República, y no podemos entrar en el camino de que la apelación al Jefe del Estado sea en la oposición un paño de lágrimas para nuestra apetencia de Poder y en el Poder un paño de lágrimas para nuestra flaqueza de gobernantes. [...]. ¡No, no!; tan garantía del Régimen republicano tiene que ser un Poder como otro: el Presidente de la República en su función constitucional, y el Parlamento, y el Gobierno, y el maestro de escuela, y el guardia civil; el que se sienta inservible, en vez de respaldarse en el inmediato e ir echando de unos a otros la carga, que lo deje». 
Sea de ello lo que sea, lo que ahora nos interesa es que, como no había de constituir un misterio la comprensión que Heller tiene sobre esta problemática es bien diversa a la de Schmitt. Como no podría ser de otra manera, también vinculará el constitucionalista socialdemócrata las figuras del estado de excepción y suspensión constitucional con la soberanía. Circunstancia ésta que parece acercar a nuestro autor a las tesis de Schmitt. De hecho, no faltó quien así lo entendiese; incluso entre sus propios correligionarios hubo quien, desde la publicación, en 1927, de La soberanía, procedió a poner en duda la firmeza democrática de las convicciones políticas hellerianas.

Nada hay, sin embargo, de correcto en estas últimas apreciaciones. Ha de tenerse en cuenta que Heller se separa, de manera radical, de Schmitt en cuanto al significado real del artículo 48 de la Constitución alemana de 1919. En efecto, para el autor de la inacabada Teoría del Estado, aquél precepto, lejos de convertir al Presidente de la República, en cuanto decide sobre el estado de excepción o emergencia, en soberano, lo que hace, por el contrario, es confirmar, por un lado, al Pueblo como único titular de la soberanía en el Estado Constitucional democrático, del que la República alemana no era más que una de sus primeras manifestaciones históricas, y, además, y por otro, la naturaleza de pouvoir constitué del Presidente del Reich. Su conclusión, por lo demás, es muy clara. Y no podía estar formulada en unos términos más contundentes: «De ahí [escribirá Heller] que en la República de Weimar, la fórmula de Carlos Schmitt: «Soberano es aquél que decide definitivamente si rige el estado de normalidad», deba aplicarse, a no al presidente del Reich, sino al pueblo».

Se comprende, de esta suerte, el por qué decíamos antes que los temores y las dudas sobre el posicionamiento real de nuestro autor eran totalmente infundados. La apuesta de Heller por la Democracia es, también en la década de 1920, clara, plena, total y definitiva. Lo que hace a partir de 1931, cuando el nacional-socialismo se presenta como una amenaza real que puede alcanzar en cualquier momento el poder, incluso a través de unos comicios, no es más que ratificar y confirmar su postura democrática. Así lo hace, en efecto, en aquélla proclama de 1931, conforme a la cual los socialistas «Como fundamento de legitimación de la organización autoritaria del Estado hacemos valer sólo al pueblo, al pueblo como portador de determinados valores que posibiliten la cultura, y no como masa de opiniones e intereses arbitrarios. [...] así como no queremos prescindir de la legitimación democrática, de igual manera tampoco queremos estar privados bajo ninguna circunstancia de la legalidad del Estado de derecho en una constitución alemana. Deseamos el Estado autoritario, pero luchamos contra el Estado totali.

Que, en marzo de 1933, y teniendo en cuenta lo hasta aquí visto, Heller no podía mostrarse optimista por la aprobación de la Ley de Plenos Poderes, es algo 
que, sinceramente, nos parece incuestionable. Que a una tal opinión habría de llegar no sólo desde la mera especulación intelectual, tampoco parece discutible. Recuérdese que, en 1932, nuestro autor había visto cómo Franz von Pappen se había servido del artículo 48 para, merced una interpretación extensiva de éste, proceder a la disolución del Gobierno del Land de Prusia, presidido por el socialdemócrata Otto Braun, y que en este conflicto Heller no había permanecido en el papel que supuestamente corresponde a los académicos de mero espectador externo, sino que actuaría como jurista práctico, asumiendo la defensa del gobierno autonómico ante el Staatsgerichshof de Leipzig, enfrentándose, una vez más, a Carl Schmitt, que actuó como valedor de von Pappen ante el tribunal.

En tales circunstancias, evidente ha de ser que Heller tendría, de manera obligatoria e inevitable, que concluir que la atribución de plenos poderes a Hitler tan sólo podía deparar una utilización fraudulenta y torticera de la llamada «cláusula dictatorial» del Código Constitucional de Weimar. Dicho de otro modo, que la aprobación de la Ley de Plenos Poderes tenía como única y exclusiva finalidad la de, ante el silencio culposo de no pocos juristas partidarios, en general, del sistema democrático y la aprobación dolosa de los juristas y politólogos favorables al totalitarismo, convertir fácticamente una «dictadura comisoria», que es, en rigor, la que había recogido el Constituyente de Weimar en el artículo 48, y que, en todo caso, es la única compatible con el Estado Constitucional mismo, en una auténtica "dictadura soberana» en la que, al perderse toda referencia al Poder Constituyente originario, el dictador, en palabras de Schmitt, «ve ahora en la ordenación total existente la situación que quiere eliminar mediante su acción. No suspende la Constitución existente valiéndose de un derecho fundamentado en ella y, por tanto, constitucional, sino que aspira a crear una situación que haga posible una Constitución, a la que considera como la Constitución verdadera. En consecuencia, no apela la Constitución existente, sino a una Constitución que va a implantar».

\section{4.- SU PREVISIBLE SITUACIÓN PERSONAL EN LA DICTADURA COMO CAUSA DEL EXILIO: HELLER COMO «ENEMIGO TOTAL»}

Todo lo anterior conduce, como es obvio, a una situación objetiva ciertamente oscura y deplorable. Sobre todo, si tomamos en consideración que lo que el triunfo del totalitarismo nacional-socialista venía a destruir fue el instrumento de gobierno que había inaugurado el Estado Constitucional democrático en Europa. Siendo así, innecesario un debiera ser afirmar que para cualquier ciudadano alemán decente, que estuviera, en mayor o menor medida, compro- 
metido con el proyecto que demócratas, demócratas radicales y, de manera fundamental, socialistas democráticos habían puesto en marcha, el escenario que en 1933 se les presentaba habría de resultar en extremo dramático. Ninguno de ellos podría avenirse mansamente a la destrucción de una obra democrática cuya finalidad última no era sino la de conseguir la liberación del ciudadano, y cuyo fracaso no se debía al contenido y fines del proyecto en sí, sino a la incapacidad que los nuevos gobernantes mostraron para llevar a buen puerto aquél como consecuencia de una crisis económica que se había generado en el marco del Estado Constitucional liberal, y que no podían atajar adecuadamente por tener que trabajar sobre las ruinas del viejo Estado liberal.

Heller no podía ser ajeno a esta circunstancia. En su doble faceta, aunque para él, oponiéndose a los planteamientos del positivismo de toda especie — que, por lo demás, resultaban, como ha puesto de relieve el Maestro De Vega, falaces y absolutamente contrarios a la propia lógica científica en el campo del Estado, la Política y el Derecho-, inseparables, de Profesor universitario y de militante del SPD, adscrito a lo que se llamaba el «ala izquierda» del partido o «socialismo radical», había dado pruebas bastantes de su compromiso y adhesión a la República de Weimar y a su Código Constitucional. Como académico, bien conocido es, realizando unos estudios siempre críticos, aunque manteniéndose, como no podía ser de otro modo tratándose de un demócrata en el sentido más amplio de esta expresión, en el ámbito de la crítica inmanente, tendentes a la mejora futura la situación constitucional creada por el Texto de 1919. Como político práctico y pensador socialista, su compromiso quedó expresa, tajante e incuestionablemente demostrado en el discurso pronunciado ante la Asamblea Alemana de Estudiantes con motivo de la festividad de la Constitución: «Celebramos la Constitución de Weimar, no porque esté para nosotros ya consumada, sino porque nos posibilita nuestra tarea. [...] La protegemos y exigimos para ella respecto, porque nos concede la libertad de realizar en el futuro una forma superior y más homogénea. [...] Tenemos derecho a exigir respeto para ella a todos los ciudadanos alemanes de todas las orientaciones políticas, [...] Nosotros nos comprometemos a defender la Constitución de Weimar frente a todos los ideólogos de la violencia. [...] Sabemos muy bien que un Estado no se garantiza solamente con las papeletas de voto, y les probaremos este conocimiento de manera práctica en el momento en el que intenten una agresión violenta. ¡Entonces defenderemos la Constitución de Weimar, si es preciso con las armas en la mano!».

Se comprende, en tales circunstancias, que Heller hubiese pensado en la posibilidad del exilio. Y que una tal opción se debiera a la impotencia de la razón frente a la barbarie. No sería, sin embargo, descartable que, siendo nuestro autor 
un hombre optimista, voluntarioso y en extremo convencido en la potencialidad del espíritu, a Heller se le hubiese ocurrido también, y todavía en un orden de consideraciones generales y objetivas, la posibilidad de volver a Alemania y, en cuanto que intelectual comprometido social y políticamente, autorizado, ahora, a llevar a cabo la crítica transcendente y a encabezar la oposición ideológica al poder, proceder a la denuncia de la dictadura nacional-socialista y, en consecuencia, propugnar la vuelta los esquemas de la legalidad y legitimidad democráticas que aquélla había arrumbado.

Y es aquí donde, lógicamente, entrarían en un juego consideraciones de índole subjetiva que apoyarían la opción del exilio. Sí creo estar en lo cierto al pensar que Heller, tomando en cuenta tanto los elementos subjetivos a los que antes aludíamos como los objetivos, hubieran acabado decidiendo lo que decidió por sí mismo, he de decir, no obstante, que la intervención de sus amigos en aquel marzo de 1933 no fue irrelevante. El aviso de éstos tuvo, sin duda alguna, la enorme virtualidad de hacerle reflexionar, si es que no lo había hecho ya, sobre la suerte que podría correr en una Alemania gobernada por Hitler.

Reflexionando sobre su posición personal en el totalitarismo nazi, Heller, de manera inevitable, y con independencia de que sus buenos amigos le hubieran comunicado sus temores al respecto, habría llegado a la convicción, absoluta y, como les gusta decir a los juristas, como una presunción iuris et de iure, de que, antes o después, y más bien antes que después, él sería represaliado por el Gobierno del Führer. Lo que, entendemos, no ha de ser muy difícil de comprender, ni de compartir. En efecto, Heller, sagaz y perspicaz como era, no podía ignorar que, concebida la política por los partidarios del totalitarismo en los términos de la clásica la dicotomía schmittiana, a él habría de corresponderle en la etapa hitleriana la condición de "enemigo" del Reich nacional-socialista. Lo que, en última instancia, significa que, al igual que le había ocurrido a muchos intelectuales italianos, y con la misma justificación filosófica: el nacionalismo más irracional, mítico y místico, y desde la absoluta y total identificación del líder fascista con la Nación misma, todas sus construcciones políticas -académicas o prácticas-, en cuanto que críticas con el dictador, serían calificadas, de manera irremediable, de ataques a la Nación y, en consecuencia, convertirían a su autor en merecedor de la más dura represión. De igual manera, sabía nuestro autor que siendo partidarios los nacional-socialistas, siguiendo el ejemplo de los fascistas italianos, de llevar a la dialéctica "amigo-enemigo» a unos extremos a los que ni siquiera Carl Schmitt, mucho más inteligente que la mayoría de sus correligionarios, había previsto, -recuérdese, en este sentido, que para éste aquélla contraposición había materializarse tan sólo en el ámbito de la política, y que no resultaba de recibo el extender su vigencia al resto de los ámbitos de la vida, de 
suerte tal, y esto es lo importante, que al enemigo político, que " no necesita ser moralmente malo; ni estéticamente feo; no hace falta que se erija en competidor económico, e incluso puede tener ventajas hacer negocios con él», sino que tan sólo es percibido como diferente y, por ello mismo, como auténtico hostis, «no hace falta odiarlo personalmente» - a él no le correspondería la mera la condición de «enemigo político». Por el contrario, sería considerado como un «enemigo total».

\section{1.- Su inevitable condición de «enemigo personal» del régimen, o de los orígenes biológicos como causa de persecución}

Que Heller únicamente podía ser considerado por los nazis como un «enemigo personal», al que, de acuerdo con la propia lógica schmittiana, sí es necesario odiar y, por ello mismo, ha de buscarse su eliminación y, si fuera posible, su destrucción, es algo que resulta, según nuestro parecer, indiscutido e indiscutible. Basta con tomar en consideración que aquél que había llegado a ser el más lúcido, válido, capaz y coherente constitucionalista del período entre guerras $-\mathrm{y}$, acaso, de todo el s. XX-, había nacido en el seno de una familia de origen judío. Y ello, bien conocido es, constituía para hitlerianismo una ofensa suficiente, e imperdonable. Por lo menos, esto era así salvo que el afectado estuviese, de modo que sea, en el círculo vital del Führer.

Interesa advertir que, en realidad, lo anterior no es más que una de las lógicas consecuencias de la conexión entre el totalitarismo fascista y aquel nacionalismo romántico, irracional, espiritual, mítico y místico que, a finales del siglo XVIII, había comenzado a formular Herder, y que, desarrollado en toda Europa a lo largo del XIX, se haría especialmente fuerte en la primera mitad del siglo XX. Veámoslo.

Sin pretender caer en una injustificable simplificación que no tomara en cuenta la existencia de la multiplicidad de matices que hay entre unas y otras corrientes nacionalistas, podemos afirmar que esta manifestación del nacionalismo al que nos referimos nace en una completa y radical oposición a ese primer nacionalismo racional que, encontrando su más claro precedente y su más notable definidor en Nicolás de Maquiavelo (P. De Vega), y estando inescindiblemente unido a las ideas democrático-liberales (Heller), había hecho su entrada en escena de la mano de la Revolución francesa, y, de manera esencial, gracias a las tesis de los jacobinos. Nos sumamos, de esta suerte, a la tesis defendida por De Vega sobre este particular. En concreto, advertirá el Maestro que «la sima abierta entre la utopía humanitaria, igualitaria y liberal de la revolución francesa y la 
práctica social burguesa, llena de desigualdades y conflictos, no va a permitir por mucho tiempo seguir apelando a una ideología que en la realidad está mostrando su escasísima virtualidad integradora. La pervivencia unitaria de los Estados ya constituidos, y sobre todo, la integración nacional para los Estados que van a crearse [...], no se buscará ya en la realización de la democracia, sino que se abrirá camino por otros derroteros. Antes y por encima del Estado liberal, como elemento aglutinador de un pueblo, está la nación. Antes de los sentimientos de igualdad y libertad forjados en la especulación racionalista, están los sentimientos telúricos que vinculan al hombre a la tierra donde nace y donde muere. [...] Surge este modo un nacionalismo romántico y sentimental, montado sobre la exaltación irracionalista y mística de la Nación y que, [...], se desarrolla y tiene sus defensores, más o menos notables, en todos los países. [...] La necesidad de conservar el control del Estado, en aquellos países donde la unidad estaba ya lograda, y la necesidad de crear la unidad estatal en aquellos que en vivían desperdigados [...], constituye la más urgente tarea política de la burguesía decimonónica. [...] Ahora bien, este tipo de apelaciones [...], no podrá realizarse ya en el transcurso del siglo XIX y, sobre todo, a partir de su segunda mitad, [...], en nombre de la libertad y de la democracia. Se apelará entonces a la idea de nación y se presentará al Estado como el gran defensor el realizador de sus potencialidades. De esta forma la taumaturgia política opera el gran milagro: el Estado controlado y dirigido por la burguesía, y que lógicamente va a ser quien le ayude a satisfacer sus intereses, ocultando sus efectivos papeles, va a aparecer como el realizador y defensor de los intereses de la nación. [...]. Ahora la nación va a convertirse en una especie de fantasma, de contornos indefinidos y confusos, que requerirá un poderoso acto de fe para poder llegar a identificarla».

Aceptado lo anterior, evidente resulta que esta nueva forma del pensamiento nacionalista sólo, y en tanto en cuanto, y como observó Heller, se apartaba de manera total y absoluta de las ideas democrático-liberales y universalistas nacidas con las grandes revoluciones liberal-burguesas del siglo XVIII, adquiere la plenitud de su sentido cuando la defensa de la Nación, y la consecuente salvación de los valores nacionales, se lleva a cabo en contraposición a otras Naciones y a otros valores nacionales. Lo que, obviamente, y aunque partiendo de los más diversos fundamentos y manifestando muy distintos matices, conlleva la necesaria identificación de la Nación con un espacio físico-geográfico determinado, y hará de éste, así como de la pertenencia a él, los elementos centrales, capitales, nucleares y basilares de la ideología de la Nación. Esto es, frente a la concepción del nacionalismo jacobino que se expresaba en aquellas palabras que, el 7 de febrero de en 1794, había pronunciado Robespierre ante la Convención, y en las que, desde la aceptación plena e incondicionada de la virtud política ma- 
quiavélico-rousseauniana, afirmaba: «¿Y qué es la Patria sino el país del que se es ciudadano y participe de la soberanía? [...] Por una consecuencia del mismo principio, en los Estados aristocráticos, la palabra "patria» sólo tiene algún significado para quienes han acaparado la soberanía. [...] Sólo en la democracia es el Estado verdaderamente la patria de todos los individuos que lo componen, y puede contar con tantos defensores interesados en su causa como ciudadanos tenga» —que, en la España del primer tercio de la pasada centuria, encontraban su más puro correlato en las de aquel joven Azaña ante sus posibles votantes de Puente del Arzobispo-, en el que la Nación, la Patria o el Estado, identificándose con la Democracia misma, y con total independencia del espacio geográfico en que pueda actuar o encarnarse, se presenta como el amor a las leyes que libremente se dan los ciudadanos y el amor a la igualdad, en el sentido de que, como afirmó «El Incorruptible», «como la esencia de la República o la democracia la igualdad, el amor a la patria incluye necesariamente el amor a la igualdad»; este nuevo nacionalismo romántico, irracional, mítico y místico vinculará la esencia de la Nación a una serie de sentimientos telúricos que, en última instancia, remiten a la pertenencia del hombre a la tierra en que nace, vive y muere. Idea ésta que, sin que pueda discutirse, encontrará en aquél «la tierra y los muertos» debido al nacionalismo determinista de Maurice Barrès, y del que, como señaló Azaña, se deriva que «de dos modos se infringe la ley que los muertos y la tierra dictan. Primero, arrancando materialmente a los hombres de la inmediata tutela de la tierra, poniéndolos lejos de ella [...]; segundo, por una educación que pretenda orgullosamente proveernos de una norma de conducta, cuyo valor sea extraño a todo relativismo y se presente como universal».

Poco importa, a los efectos que aquí, y ahora, interesan, el detenerse a indicar que, en realidad, lo que este nuevo nacionalismo hace es retrotraer la evolución del pensamiento político y constitucional a aquellos esquemas que actuaban en el momento en que la forma política «Estado» hacía su entrada en la Historia en el que, como puso de manifiesto Tierno Galván, se procedió a la justificación de aquél con la formulación de la tradición nacional mágico-mítica. Nos referimos, de una manera más concreta, a la circunstancia de que, aunque sin ese carácter racista que adquirirá el nacionalismo un momento posterior, los intelectuales, artistas y juristas al servicio del rey trataron justificar el Estado en base a la su propia individualidad respecto de los otros territorios agrupados en el Imperio, y que se pretendía explicar, justamente, atendiendo a los orígenes raciales o étnicos que imperaban en ese determinado y concreto territorio.

Mayor interés tiene advertir que de esta circunstancia a la que aludíamos, se derivan unas diferencias sustanciales en el plano político entre el primer nacionalismo, el jacobino, y el nacionalismo romántico, irracional, mítico, místico y 
espiritual. Divergencias cuyo recordatorio resulta singularmente oportuno realizar el contexto de la realidad jurídica y política que se ha generado en España desde 2003, con la apertura del proceso de reforma estatutaria, en realidad un nuevo proceso estatuyente. Aunque, como es indudable, podríamos establecer muchas más, ahora, y para no hacer interminable este escrito, vamos a limitarnos a las tres más evidentes.

La primera de ellas, se refiere al distinto modo en que uno y otro nacionalismo van a articular el proceso de toma de decisiones políticas fundamentales en la Comunidad Política. A nadie le puede caber la más mínima duda, a este respecto, sobre el dato de que para el nacionalismo jacobino, nacido en el ámbito de las ideas democrático-liberales, la titularidad de aquélla facultad ha de corresponder al Pueblo, y sólo a él. Pero, y esto es lo realmente importante y lo que resulta transcendente, se trata de un Pueblo que, concebido desde los esquemas conceptuales del Maquiavelo teórico de la Democracia, se presenta como una entidad real, histórica y concreta. Todo lo contrario sucede en el supuesto del nacionalismo romántico, irracional, mítico y místico. También éste apelará, bien conocido es, a la voluntad del Pueblo. Ahora bien, ocurre que, por partir de una exaltación mística y, en cierto modo, divinizadora de la Nación, el Pueblo con el que opera el nacionalismo romántico y irracional pierde, de forma tan necesaria como inevitable, ese carácter histórico, temporal y concreto, para convertirse en un ente abstracto y atemporal, al que pertenecen las generaciones pasadas, presentes y futuras. Lo que, traducido en otros términos, significa que el proceso de toma de decisiones políticas fundamentales recupera aquellos caracteres que lo habían definido hasta la obra maquiavélica, y de una manera fundamental en la Grecia y Roma clásicas, donde, como ha puesto de relieve el Maestro De Vega, «no es de la voluntad democrática del pueblo de la que dependía al destino de las polis [...] o de la civitas [...], sino que era de las voluntades misteriosas de la polis o de la civitas, concebidas como auténticas divinidades, de las que dependía la voluntad del pueblo».

Se comprende, en este contexto, el porqué se ha podido afirmar, y de manera generalizada, el carácter claramente conservador y antidemocrático del nacionalismo romántico, sobre todo cuando éste abandona ese racionalismo liberaldemocrático, que todavía encontramos en Fichte, y adquiere su naturaleza irracional, mítica y mística. Se comprenden también, según nuestro parecer sin dificultad alguna, los grandes inconvenientes que encuentra el actual nacionalismo conservador vasco para entender los más elementales fundamentos del moderno Estado Constitucional, que, por decirlo con Hermann Heller, se concretan en el principio de que la voluntad del Pueblo como unidad, adoptada por mayoría, se impone, por ser la voluntad del soberano, a todos, incluso a los disi- 
dentes que están en minoría, así como la imposibilidad que tienen para aceptar que una decisión del Tribunal Constitucional tendente a hacer prevalecer aquella voluntad frente a la de los poderes constituidos no supone una ataque político-existencial y total a la Nación vasca, que, por lo demás, y en su condición de Pueblo como diversidad decidió incorporarse libremente al Pueblo como unidad, sino la más nítida y pura materialización de la lógica democrática.

La segunda gran diferencia entre ambos momentos de la ideología de la $\mathrm{Na}$ ción, aparece referida al sistema de relaciones de la Nación, o del Estado, con las demás Comunidades Políticas. El nacionalismo jacobino, de naturaleza racional liberal-democrática, hizo suyo, como seguramente no podría ser de otro modo, todo el contenido de todas las construcciones utópicas sobre la paz, las cuales culminaban en las especulaciones kantianas sobre "La paz perpetua», en donde, por decirlo con De Vega, «se vincula la paz a la democracia. Ambos términos se entrelazan y confunden. Se pudiera sostener que la democracia es la paz y que el triunfo de la democracia es el triunfo de la paz». Idea ésta que, como, en la España del primer tercio del siglo XX, pondría de manifiesto el más claro representante español del pensamiento jacobino cuando afirmaba que «la República significa la paz; la paz en el exterior y la paz en el interior del país» (Azaña), trataría de hacer real y efectiva no sólo en el interior de la propia Comunidad Política, sino en las relaciones de ésta con los demás Estados. Consecuencia de ello sería, primero, el que, como proclamaría enfáticamente el Constituyente español en el artículo 6 del Texto de 1931, el nacionalismo jacobino «renuncia a la guerra como instrumento de política nacional», bien entendido que, como aclararía Azaña, a los efectos de la guerra y de la defensa el término «política nacional» se refiere también a la proyección internacional de la línea de política nacional. Segundo, que el nacionalismo jacobino, que renunciaba a la guerra como instrumento de política internacional, se mostrará proclive a la articulación de relaciones pacíficas y de convivencia democrática con las demás Naciones, ya sea a través de las relaciones bilaterales, ya sea mediante la creación de estructuras supranacionales tendentes, al modo kantiano, a asegurar la paz en la comunidad internacional.

Todo lo contrario sucederá con el nacionalismo romántico. En efecto, la perentoria necesidad experimentada por éste de reafirmar su individualidad y su esencialidad, determinaría, de manera inevitable, el que la política nacional se materializase en el plano internacional en la desconfianza de la Nación hacia las demás entidades del Derecho Público Internacional. Y esto es así en todas las manifestaciones del nacionalismo romántico. Participará, incluso, de esta idea aquel nacionalismo romántico mantenido por Fichte, el cual, al decir de Heller, se mantiene en el cuadro del pensamiento racionalista, se inspira en las ideas li- 
beral-democráticas y socialistas y, finalmente, tiene todavía un alto grado de universalismo o cosmopolitismo.

Recuérdese que, en la obra en la que se culmina su tránsito del liberalismo social al socialismo científico (Heller), Fichte defenderá, en lógica coherencia con su postura nacionalista romántico racional, la puesta en marcha de un «Estado comercial cerrado», que definiría en lo siguientes términos: «Una cantidad de hombres sometidos a las mismas leyes y a un mismo poder coactivo supremo forma un Estado jurídico. Pero si esta cantidad de hombres se limita ahora, a la actividad interna del mutuo comercio de unos con otros y a la producción de unos para otros, y se excluye la participación en esas relaciones a todo aquel que no esté sometido a la misma situación y poder coactivo, entonces esta cantidad de hombres formaría un Estado comercial, y, de hecho, un Estado comercial cerrado, lo mismo que ahora constituye un Estado jurídico cerrado». Ni que decir tiene que lo que subyace en estas palabras es la tesis del aislacionismo estatal, común a todo nacionalismo romántico, y que en nuestro autor conocerá alguna matización derivada de sus convicciones cosmopolitas. En este sentido, debemos a De Vega la acertada observación de que «Fichte había propugnado, junto a la conveniencia de la unificación del pueblo alemán, la conveniencia de que ese mismo pueblo se cerrara en la demarcación de sus fronteras para salir luego, una vez desarrollados todos sus recursos, a cumplir sus misiones cosmopolitas y civilizadoras".

Lo de menos sería detenerse aquí a indicar que las concepciones fichtianas sobre el Estado comercial cerrado, que en el plano jurídico-normativo encontraron, de una u otra suerte, su materialización en el establecimiento, en 1818, y bajo la dirección de Wilhelm von Humboldt, de la Zollverein (Unión aduanera) en Prusia - y que, en virtud de aquélla medida, y por su situación geopolítica, se configuró como la unidad que « estaba llamada, cuando menos en el terreno económico, a realizar la unidad alemana. [...]. Se creó una estrecha comunidad de tráfico dentro de un amplio territorio, que ofrecía a la vida económica alemana muchas de las ventajas de un gran Estado, y constituía un poderoso trabajo de avanzada hacia la unidad alemana» (Heller)—, serían, en primer término, fielmente desarrolladas por aquel ilustre patriota y demócrata suabo, y del que, no sin falta de razón, se ha dicho que fue el gran teórico de la Zollverein, que era List. Éste, en efecto, siguiendo los esquemas propuestos por Fichte, combatiría el dogma del librecambismo cosmopolita proponiendo, desde la idea de que la economía de una Nación políticamente organizada constituye una unidad, un sistema proteccionista y aislacionista o autárquico. Tesis ésta que, con un carácter general, había defendido ya en 1827 con la sentencia «El fin de la Economía de esa corporación no es sólo la riqueza, como en el de la Economía 
individual y cosmopolita, sino el poder y la riqueza, pues la riqueza nacional se aumenta y asegura por el poderío nacional. Sus principios directores no son, [...], exclusivamente económicos, sino también políticos», y que posteriormente, y proyectándolo sobre Alemania, concretaría en la idea de que "La independencia y el futuro de la nación alemana descansan en el establecimiento de un sistema aduanero proteccionista alemán. Cada nación debería tender a producir dentro su propio territorio todo lo necesario para el mantenimiento de la vida nacional». Es menester indicar, en segundo lugar, que la hipótesis del Estado comercial cerrado es también constatable en la obra, de la década de 1850, de Biedermann; filólogo de Leipzig que, como nos dice Heller, también concebiría la Nación alemana, y su unidad, desde parámetros económicos aislacionistas.

No es especialmente relevante aquí el advertir la paradoja que generó la idea del Estado comercial cerrado en el ámbito de la práctica política. Nos referimos, claro está, al hecho de que si bien este aislamiento económico nacional encontró su origen en el ámbito del pensamiento socialista, que lo había formulado en contraposición a las tesis del liberalismo económico inglés, -articulado, como ha puesto de relieve Heller, sobre la doble idea de que, por una parte, la economía, que ha de permanecer al margen de la actuación del Estado, ha de regirse según sus propias leyes y, de otra, la «libertad de comercio habría de provocar un equilibrio entre los intereses nacionales y los internacionales, realizar la ciudadanía universal y eliminar la violencia de la vida los pueblos»-, que había preponderado en el siglo XVIII y los primeros años del XIX, es lo cierto que aquél resultó singularmente atractivo para la clase burguesa. Y no únicamente para la burguesía alemana, interesada, como lo estaba también Fichte cuando había formulado tal tesis, en alcanzar la unidad nacional y, en definitiva, en la construcción de un nuevo Estado. Por el contrario, y como advierte De Vega, fue toda la burguesía europea la que se sintió atraída por la lógica que se derivaba de aquella concepción, y, en consecuencia, trataría de ponerla en marcha en el ámbito de la práctica política estatal ya se tratase de Comunidades Políticas de antiguo configuradas como Estados, ya en aquellas otras que pugnaban por erigirse en tales. Y no puede olvidarse, en este sentido, que fue en otros Estados, como, por ejemplo, la Francia de Napoleón III, donde este nacionalismo económico tuvo sus mayores éxitos.

Lo que nos importa es señalar que el nacionalismo romántico ya irracional, espiritual, mítico y místico iniciaría también su andadura política con este espíritu de favorecer el aislamiento de la Nación en un marco de convivencia pacífica con aquellas otras Naciones de las que trataban de diferenciarse y de las que, por lo demás, no acababan de fiarse. Tal era, como, por ejemplo, nos recuerdan un Heller o un De Vega, y aunque con alguna matización, el supuesto 
de Herder. Recuérdese que éste había afirmado la tesis de la incomunicabilidad de las almas y de las culturas nacionales, que, de manera inevitable, remite a la idea de la necesidad de que las Naciones, precisamente para poder desarrollarse, habrían de aislarse y constreñir su actuación al marco geográfico determinado por sus fronteras. Aislamiento que, según Herder, podría realizarse de forma pacífica en tanto en cuanto que los buenos patriotas burgueses no guerrearían entre sí, sino que se apoyarían pacíficamente como una familia. La Nación, y sus nacionales, debían, entonces, dedicarse al desarrollo de su propia entidad. Entidad ontológica ésta que, como nos recuerda Azaña, para Herder se concretaba en que en «La ocupación nacional de los alemanes [...] es la filosofía; la gloria de este pueblo de de constituir precisamente en el olvido de sí mismo y en consagrar su vida al progreso de la humanidad; todos los alemanes deben trabajar en esa obra sin fines de interés público ni privado. No importa [...] que este desinterés exponga Alemania a ser explotada y humillada, porque es un destino sublime vivir para los demás». Ésta beatífica proclama no deja, sin embargo de esconder un cierto espíritu imperialista — que, por lo demás, y como advierte De Vega, resulta inherente a todo el nacionalismo romántico fundamentado en la filosofía irracionalista-, y que se hacía expreso en la afirmación textual herderiana de que «La vocación del pueblo alemán es la Filosofía. Adoctrinando a la humanidad cumplirá su destino; por la Filosofía ganará Alemania la veneración de todos los hombres, como madre y maestra suya».

Ahora bien, si esto es así, debemos advertir, de modo inmediato, que este inicial "pacifismo", expresado en el lenguaje mesurado de Herder, sería pronto abandonado por el nacionalismo romántico, espiritual y místico. Y lo sería, justamente, como consecuencia de los propios presupuestos sobre los que se había edificado esta manifestación de la ideología de la Nación. De Vega ha realizado una observación fundamental a este respecto, y que, por compartirla de manera plena y total, no podemos dejar de transcribirla: «Ahora bien [escribió el Maestro], [...], no se pueden exaltar los valores nacionales y mucho menos, en épocas de presión, exacerbarlos, sin contraposición a otros países y a otras culturas. De este modo, la proclamación de los valores propios termina exigiendo, por un proceso lógico elemental, la destrucción y el aniquilamiento de los demás. Por eso, si Herder emplea todavía un lenguaje mesurado, [...], el lenguaje de un Trietschke, un Jahn o un Clausewitz tomará unas tonalidades radicalmente diferentes».

Cuando, en el transcurso de la lucha político partidista, el nacionalismo romántico fundamentado, como venimos señalando, en la filosofía irracionalista se vio en la necesidad de recurrir a los argumentos con los que justificar sus pretensiones, y, para ello, acudiría a la llamada «filosofía de la decadencia», esta ten- 
dencia se agudizaría. En efecto, el nacionalismo degenerará, bajo la más que sobresaliente influencia de Nietzche — quien, en su célebre "Asi habló Zaratustra", afirmaba que «Debéis buscar al enemigo para hacerle la guerra: [...]. No debéis tener más enemigos que para odiarlos»—, y, de manera fundamental, Oswald Spengler, en un puro belicismo. Los escritos de Spengler no dejan el más mínimo resquicio a la duda en este sentido. Recuérdese que si, en su célebre " $L a$ decadencia de Occidente», Spengler, apelando al concepto de la guerra como instrumento de creación, había afirmado que «un pueblo sólo tiene realidad en relación con otros pueblos, y esa realidad consiste en los antagonismos naturales e inmediatos, en el ataque y la defensa, la enemistad y la guerra», en 1936, proclamaba que la organización internacional sólo podía basarse «en la victoria e imposición de unas culturas sobre otras».

Será, en todo caso, con los nacionalismos fascistas cuando este carácter imperialista y belicista adquiera su máxima expresión, en el entendimiento de que, para ellos, «la grandeza de la nación no sólo justifica la guerra, sino que además la exige» (P. De Vega). Mussolini lo pondría claramente de manifiesto: «Ante todo, el fascismo no cree en la posibilidad ni en la utilidad de la paz perpetua. Rechaza, [...], el pacifismo que esconde una renuncia a la lucha y una vileza frente al sacrificio. Sólo la guerra lleva al máximo de tensión todas las energías humanas e imprime un sello de nobleza a los pueblos que tienen la virtud de afrontarla. [...]. Una doctrina, [...], que parte del postulado previo de la paz es extraña al fascismo, así como al espíritu del fascismo». En la Alemania nacional-socialista, y como nos dice, por ejemplo, Fijalkowski, sería el ingenio de Schmitt el que, en los escritos redactados como Consejero de Estado a partir de 1936, justifique académicamente el belicismo imperialista de los totalitarismos fascistas.

La diferencia con el nacionalismo jacobino, e incluso con el nacionalismo romántico, aparece, en este contexto, con toda su nitidez y magnitud. Como ha escrito el Maestro De Vega, "La conclusión a que se llega podía formularse de este modo: Cabe hablar de un nacionalismo democrático y un nacionalismo totalitario y absorbente. El nacionalismo democrático [que es el que se corresponde con las ideas liberal-democráticas y que, siguiendo los esquemas conceptuales rousseaunianos, tratará de compatibilizar, en el marco de la organización democrática y con un respeto a los derechos fundamentales, el particularismo y el cosmopolitismo] es pacifista. El totalitario, por el contrario, está abiertamente en contra de la paz».

Finalmente, la última de las diferencias que existen entre el primer nacionalismo, el jacobino, y el nacionalismo romántico, espiritual, irracional, mítico y místico — que es, por lo demás, la que reviste una mayor importancia y tras- 
cendencia respecto de lo que aquí nos interesa-, se refiere también a la propia comprensión respecto de la realidad circundante. Circunstancia ésta cuya comprensión se hace fácil si se admite que, a pesar de las diferencias derivadas de los parámetros "espacio-tiempo», una y otra manifestación del nacionalismo no hacen más que repetir lo que se había generado en Europa en el momento del nacimiento del Estado moderno, y en relación con los conceptos de «Patria» $\mathrm{y}$ «Nación». A este respecto, escribió Enrique Tierno, - $-\mathrm{y}$ nosotros lo asumimos plenamente-, que la «idea antigua de patria admitía la concurrencia. Dentro de la idea de patria romana cabían diferentes pueblos y costumbres. [...]. En la patria hay un orden de concurrencia. Concurren diversos derechos, lenguas y religiones. La nación es un orden excluyente. Es una totalidad que excluye otras totalidades. [...]. Un hombre patriótico [que es al que debe ser reconducido el nacionalista jacobino] es un hombre universal, [...]. Un hombre nacionalista no puede ser universal».

En este afán exclusivista y auto-afirmador del ser nacional el nacionalismo romántico irracionalista dará un paso más. Ahora, se acudirá a factores raciales y étnico-biológicos como medio para la identificación de la Nación. Lo que, nadie puede ignorarlo, alcanzaría en Alemania, y de la mano del germanismo, su máxima expresión. Ello no obstante, es menester advertir, con Sabine, que esta asimilación en realidad había nacido en Francia, y que había conocido una muy extensa aceptación allí y en Estados Unidos, donde operaba como un magnífico instrumento para fomentar el orgullo nacional.

Partiendo de las especulaciones realizadas por Gobineau — que, en rigor, estaban redactadas en apoyo de la aristocracia sobre la democracia-, así como de las que, basándose en aquéllas, había formulado Chamberlain, se desarrollaría en Alemania, y puesta en conexión con el llamado principio germánico con el que se pretendían satisfacer las aspiraciones de la burguesía liberal-democrática (Heller), la teoría nacional étnica. De una manera muy resumida, ésta se concretaba en la superioridad de la raza blanca en su rama aria y familia germana, sobre el resto de las razas. Aserto éste que llevaría a la afirmación de la superioridad de lo germánico, que sería admitida incluso por algunos conservadores no alemanes, pero sí germanófilos, sobre todo lo demás, y que llevaría a la rara especie de que incluso los pueblos románicos en el fondo son de origen germánico.

Derivado directamente de esta concepción étnico-biológica de la Nación, aparecería el antisemitismo como un componente del nacionalismo romántico conservador. En relación con esto, ha de hacerse una doble aclaración. En primer lugar, es menester advertir que si bien fue con la teoría - con, de manera fundamental, el «Der Mythus des 20. Jahrthunderts» (1930) de Rosemberg, el «Mein Kampf» de Hitler, y el "Elementos raciales de la Historia europea» de Günther-y 
la práctica del nacional-socialismo alemán cuando el antisemitismo alcanzó su más patente, y dramática, materialización política, es lo cierto, sin embargo, que no fueron éstos los únicos nacionalistas románticos conservadores alemanes que participarían de aquél. Ahí están, por ejemplo, los nombres de Stöcker, Treitschke, Langbehm o de Lange. Pero, es más, es menester advertir que el antisemitismo operaría también entre el pensamiento político conservador y tradicionalista de toda Europa, y no sólo en Alemania. El supuesto de la Action Française es suficientemente indicativo este respecto. Bien conocido es que, bajo la inspiración del nacionalismo integral de Maurras, la conservadora Acción Francesa rechazó todos los presupuestos de la Revolución de 1789 por estar basados en ideas judías, y que, en el fondo, no era más que el reflejo del pensamiento de su ya citado líder que quedaría bien claro en la sentencia "Yo no deseo a mis compatriotas [...] el destino intelectual de un alemán o de un inglés, cuya cultura, desde el idioma hasta la poesía, está toda infestada, hace ya tres siglos, de hebraísmos deshonrosos».

En segundo término, debe hacerse notar que aunque, como decimos, todo el nacionalismo romántico, espiritual, irracional y conservador participó de este sentimiento antisemita, ocurre que, como puso de relieve Heller, no todos adoptarían la misma postura. Así, nos encontramos con que, por ejemplo, Treitschke recomendaría la mezcla de sangre para solucionar la cuestión judía. Otros, por el contrario, adoptarían una actitud combativa y de eliminación del judío. Opción ésta última que haría su entrada en la vida pública alemana con la fundación, en 1894, de la Liga alemana aria por parte de Friedrich Lange.

Como a nadie se le oculta, sería a esta última corriente a la que se adscribiría Hitler. En efecto, y como nos dice Sabine, éste hacía suyas las conclusiones que se derivaban tanto del mito racial como de la Lebensraum (doctrina del espacio vital) y, desde ellas, procedería a la concreción de la Nación en las máximas «Volk und Rasse» ("Pueblo y raza») y «Blut und Boden» (»sangre y tierra»). En ellas, se condensa la idea de la superioridad de la raza blanca, sobre todo en su variante ario-germánica, que, precisamente por ser superior, ha de servirse del resto como meros instrumentos auxiliares. Lo que, como es obvio es, se traduciría en afirmación de la existencia de un derecho de los ario-germánicos a dominar tanto a los demás blancos, como a los judíos, negros y amarillos — que serviría, al mismo tiempo, para justificar la política imperialista del régimen nacional-socialista-, y el correlativo deber de éstos, en cuanto que supuestas razas inferiores, a someterse dócilmente a la voluntad de aquéllos, incluso aunque ésta fuese la de decretar su eliminación y destrucción física.

En marzo de 1933, Heller conocía perfectamente esta situación. De hecho, llevaba ya años denunciándola tanto como estudioso del Estado, la Política y el 
Derecho, como en su condición de demócrata práctico de la política adscrito al Partido Socialista alemán. En una y otra faceta, nuestro muy brillante constitucionalista y politólogo había dado pruebas de que él ni, por un lado, admitía la pretendida superioridad aria, ni, por otro, estaba dispuesto a convertirse de manera voluntaria en servidor, o esclavo, de alguno de sus compatriotas, fuese cual fuese su origen étnico-biológico. De esta suerte, fácil habría de resultarle imaginar su fortuna bajo el gobierno de un partido totalitario nacionalista que, como hemos visto, hacía de la identificación de la Nación con la tierra, la sangre y la raza su razón de ser. Y ésta, nadie puede ignorarlo, y Hermann Heller menos que ninguno, no podía ser sino adversa. Su destino sólo podía ser el de ser perseguido y represaliado por motivos raciales. Su opción por el exilio, que, por lo demás, no hacía más que preludiar la de otros muchos anónimos o ilustres judíos alemanes y de los territorios conquistados o anexionados, se convertía en una decisión lógica y, sin duda, la única válida para conservar su propia vida.

\section{2.- Heller como «enemigo académico»}

Si, como acabamos de ver, a Heller, como consecuencia de sus orígenes étnico-biológicos, tan sólo le cuadraba la condición de "enemigo personal» de unos gobernantes que actuaban desde la irracional lógica del nacionalismo racista, resulta, en nuestra opinión, difícilmente cuestionable que, en el contexto político-universitario que se inauguraba con el acceso al Gobierno de Hitler, y de la atribución a éste de los plenos poderes, que a nuestro autor había de ser considerado como un verdadero, y harto peligroso, «enemigo académico» para los nuevos detentadores del poder en el Estado alemán. Heller no podía ignorarlo, y, con toda probabilidad, sería uno de los elementos que tuvo en cuenta la hora de optar por el exilio.

Que el autor de, por ejemplo, «Rechtsstaat oder Diktatur?» iba a aplicársele, y, además, con todo rigor, la lógica derivada de la contraposición «amigo académico» versus «enemigo académico» es algo que, como decimos, se nos antoja meridiano y evidente. Aceptarlo no ha de ser complicado. Basta, en efecto, con tomar en consideración el modo en que Heller abordaba el estudio del Derecho, la Política y el Estado. Fue, en efecto, desde esa comprensión socialista del mundo desde la que Heller, en plena y total coherencia con lo que constituye la propia lógica científica en el marco de las ciencias sociales y social-normativas (P. De Vega), abordó, en primera instancia, la tarea de explicar críticamente la realidad jurídico-política del Estado, incluyendo en ello la labor de, buscando en lo devenido lo que está por devenir, intentar averiguar cuál podía ser su evolución y 
tratar, con sus aportaciones dogmáticas, de influir en esta última. Y fue, asimismo, desde sus convicciones socialistas puestas a prueba, como se corresponde a la propia razón dialéctica, con el estudio científico, desde donde Heller acabaría por llevar a cabo una toma de postura política que si en el orden de la política práctica le conducía a ratificarse como militante socialista, en el orden científico constitucional le conducían, en cumplimiento de otra de las misiones que él consideraba inherentes, e ineludibles, al oficio del constitucionalista y el politólogo, a formular las propuestas concretas con las que, según la expresión de Jellinek, pretendía contribuir a la mejora de la situación jurídica reinante en aquel momento. Propuestas que, ni que decir tiene, habrían de ser especialmente molestas para unos gobernantes que, como ya hemos visto, no tenían otra pretensión que, aunque con una escrupulosa observación de la de legalidad, destruir el ordenamiento constitucional de la República de Weimar.

Ahora bien, ocurre que, junto a esta razón — que, desde una óptica democrática, sólo puede ser calificada de injusta e irracional, y que, por ello mismo, debe repugnarnos_-, existía otra razón más para que Heller fuera merecedor del status de "enemigo académico» en del nazismo. La misma, que, en el fondo, resultaba igual de injusta e irracional que la primera, adquiría unos perfiles distintos a los de la proscripción por motivos académico-ideológicos. Ahora la persecución se derivaría de la pugna de las distintas escuelas académicas, y de sus respectivas metodologías, por hacerse con la hegemonía en la Universidad, y la proyección de aquella confrontación académica al ámbito, más general, de la vida política del Estado. Veámoslo, siquiera sea brevemente.

De todos es bien conocido, a este respecto, que ha sido una constante en la Historia la de que el ascenso al poder de los partidarios del absolutismo y del totalitarismo — que, en tanto en cuanto también partirían de la negación de la posibilidad de la discrepancia y de la de los conflictos internos, y que, en consecuencia, no dudaron en proceder a su más dura y cruel represión, pueden, de uno u otro modo, a ser considerados como los continuadores naturales de los primeros (Heller, De Vega, ...)— - se ha visto acompañado, sin excepción alguna, de la elevación de alguno de los diversos grupos académicos que operan en la Universidad a la condición de Escuela oficial del régimen. Nadie ignora, ni, según nuestro modesto parecer, puede hacerlo, que en el período entre guerras este, por lo demás más que dudoso, honor correspondió al positivismo jurídico formalista, cuyos integrantes se vieron plenamente satisfechos y aceptaron, en todo caso, muy gustosamente tal consideración. E importa indicar que si esta circunstancia pudo representar alguna novedad en el fascismo italiano, en el supuesto de Alemania, por el contrario, aquello no hacía en realidad más que confirmar la situación de preponderancia de la que la Escuela Alemana de Derecho 
Público había gozado ya en el Imperio guillermino, y como consecuencia directa del carácter marcadamente autoritario de aquel régimen.

No es éste, como es lógico, el momento oportuno para interrogarse por los motivos últimos de la alianza entre el totalitarismo fascista y el positivismo jurídico formalista. Tampoco podemos, y por razones de espacio, detenernos a explicar que pese a la extrañeza que pueda generar que unas fuerzas políticas que, bajo la influencia directa de Sorel, hacían de la violencia el fundamento nuclear de su acción política para llevar a cabo la destrucción de la Democracia, apelasen, sin embargo, a las construcciones de unos juristas y politólogos empeñados en someter toda la vida política al Derecho como medio para evitar la arbitrariedad y el abuso de poder, y en alguno de ellos, como, por ejemplo, Kelsen, como el más adecuado instrumento para la defensa y consolidación del régimen democrático, todo ello resulta fácilmente explicable y comprensible. De ello, y desarrollando los planteamientos de mi dilecto Maestro al respecto, me ocupado en otro lugar, y allí me remito.

Lo que nos interesa en este escrito es, única y exclusivamente, llamar la atención sobre que si a los totalitarismos fascistas les interesaba servirse de las construcciones intelectuales de los autores del positivismo jurídico formalista en tanto en cuanto que, como hemos visto, éstos, en su empeño por forjar una Teoría del Estado totalmente objetiva y «científica», procedieron a la elaboración dogmática de un Derecho Constitucional atemporal, aproblemático y estrictamente técnico que, fugitivo de los principios y valores del constitucionalismo moderno, facilitaba los dictadores la cobertura jurídica necesaria para llevar a cabo sus fines presentándose, empero, como gobernantes democráticos, al positivismo jurídico formalista, por su parte, le interesaba la colaboración con el totalitarismo fascista en la medida en que, en su virtud, y al verse elevado a categoría de Escuela oficial del régimen, podía satisfacer sus aspiraciones exclusivistas monopolísticas en el mundo universitario y, de algún modo, y aunque, para mantener la ficción de su apoliticismo, no lo declarasen abiertamente, el de la participación en la vida política del Estado. La Alemania hitleriana no fue, ni mucho menos, una excepción a esta regla. Así, nos encontramos con que si el fascismo italiano había podido contar con una Teoría del Estado y del Derecho Constitucional construido a su medida por los de Francisci, Chiarelli, Chimienti, Costamagna, Gentile, Panunzio, Sinagra, Volpicelli, etc., al esfuerzo de éstos se correspondería el de los Huber, Köllreuter, Rosemberg, Vögelin, Walz y, muy especialmente, Höhn haciendo lo propio para el nacional-socialismo.

Lo anterior no es muy difícil de entender. Basta, en efecto, con observar, de manera objetiva y desapasionada, la propia Historia de las Ciencias Constitucionales. Debe recordarse, en este sentido, que fue ya Triepel quien, en 1926, de- 
nunció que si en realidad había algo que definió la actitud de las escuelas positivistas respecto de todas las demás, esto fue, justamente, su poco disimulado deseo por hacerse con el monopolio en el estudio, y en la intervención en la práctica, en el ámbito del Derecho, el Estado y la Política. Para alcanzar el éxito en sus pretensiones, el positivismo jurídico formalista, _incluidos los que, como Kelsen, actuaban, o pretendían actuar, en defensa del régimen democrático-, no dudaría en aplicar, cuando menos en el orden universitario, las más consolidadas técnicas del autoritarismo: la descalificación y desprecio del enemigo al que se le acusa de actuar ideológicamente (K. Mannheim). Su táctica, en todo caso, no podía resultar más simple. Ésta, de acuerdo con Triepel, consistía en que el positivismo jurídico formalista se atribuía el derecho para otorgar «el título de honor "estrictamente jurídico" solamente a aquellas monografías jurídico-públicas que evitaban escrupulosamente todo contacto con lo político. El que no se doblega ante esta tiranía — a veces casi inquisitorial— se le ignora en el mejor de los casos».

No ha de ser particularmente complicado, y difícil, de comprender que, en el fondo, las posibilidades de éxito de unas tales pretensiones dependen de la naturaleza del régimen en el que los propios positivistas jurídico formalistas se ven obligados a actuar. En el marco de una Comunidad Política democrática, estas, de modo tan incuestionable como necesario, serían escasas. En efecto, articulada aquélla sobre las ideas del, por decirlo con Friedrich, disagreement on Fundamentals y de la discrepancia, las Escuelas positivistas, incluso gozando de la condición de ser las mayoritarias y preponderantes, habrían de respetar la propia lógica general del sistema político, siquiera sea para, con ello, lograr la consideración favorable de los gobernantes. De esta suerte, lo que sucede es que, porque en Democracia es la existencia de la oposición la que, al fin y al cabo, otorga legitimidad al poder $y$, en definitiva, al propio régimen, las Escuelas positivistas se vieron obligadas a aceptar o, mejor aún, soportar la presencia en la Universidad de otros grupos académicos discrepantes tanto en cuanto a lo que a las concepciones se refiere como en relación al método. Así, aunque tratarán, por todos los medios posibles, de evitar la expansión de los grupos anti-formalistas, la necesidad de aparentar que se aceptaban los principios democráticos y que, en consecuencia, eran aptos para actuar como consejeros o como ejecutores de la vida política ya fuera en el marco de una democracia limitada y con un marcado signo autoritario, como era la que regulaba la Constitución alemana de 1871, ya en el de la democracia plena de la República de Weimar, tolerarían la presencia de los discrepantes académicos en encuentros académicos, permanentes, —como aquellos que se organizaron en la Alemania weimariana con el nombre de "Veröffentlinchungen der Vereiningung der Deutschen Staatsrechtslehrens, en cuyo marco, por 
cierto, se desarrollaron algunas de las más fecundas polémicas entre los constitucionalistas del momento-, o esporádicos, e incluso, siempre y cuando no pudiesen evitarlo, el que los discrepantes pudieran ocupar algunos cargos de gestión pública.

La situación cambia, y de manera radical, en el marco de la dictadura. La elevación del positivismo jurídico formalista a la condición de Escuela oficial del régimen supone, en efecto, que aquélla política que Triepel había calificado de tiranía inquisitorial no va encontrar obstáculo alguno en su materialización. Las posibilidades de eliminación/destrucción de los demás grupos eran, ahora, y desde la lógica «amigo-enemigo», francas y expeditas. Y las materializarían con los más diversos modos. En este sentido, nos encontramos con que el grupo del positivismo jurídico, en su condición de Escuela oficial del régimen, podía controlar en todos sus extremos en proceso de selección del personal docente e investigador. Lo que, como nadie se le oculta, les permitía, atendiendo criterios tan científicos como la adscripción ideológica tanto del Maestro como del aspirante, impedir el acceso a la Universidad a los discípulos de los académicos adscritos a otros grupos y corrientes científicas, y, con ello, a decretar la extinción de éstos.

Mayor interés tiene, a los efectos de este trabajo, el ver cómo la tiranía inquisitorial se proyectaba sobre quienes ya formaban parte del cuerpo de funcionarios docentes universitarios del Estado. Y, a este respecto, hemos de afirmar que la táctica no pudo ser más simple. La, ya vista, abolición fáctica de la libertad del pensamiento llevada a cabo por el totalitarismo fascista, y que se había producido como una exigencia necesaria e ineludible para la propia subsistencia de la dictadura en el marco de la política general, se convertía, en el ámbito de la vida académica, en la obligaba privación de aquélla a los docentes e investigadores. Medida esta que, en primera instancia, suponía convertir la Universidad en uno de los más importantes instrumentos propagandísticos para la consolidación de la dictadura. Y ello, por cuanto que, como escribió Sabine, «Lo que Rosemberg llamaba «la vieja y funesta libertad de cátedra sin limitaciones» desapareció de las universidades alemanas, para ser substituida por la «verdadera libertad», la libertad «de ser un órgano de la fuerza viviente de la nación». [...]. En este sentido, las típicas instituciones educativas no eran las universidades sino las escuelas técnicas y las escuelas de dirigentes del partido. Los estudios sociales, [...] se convirtieron, esencialmente, en ramas de la propaganda adaptadas a la elaboración y difusión del mito racial».

La discrepancia académica devenía, de esta suerte, en discrepancia política. Y ni que decir tiene que quienes no aceptaban la imposición de los contenidos de sus explicaciones, o quienes no eran lo suficientemente hábiles como para sos- 
layar aquélla con la apelación al cripticismo, la simulación y el doble lenguaje, terminarían siendo depurados, y no únicamente en el ámbito académico-universitario, sino también, y con la misma intensidad, políticamente.

De cualquier modo, es menester advertir, de forma inmediata, que la abolición fáctica de la libertad de cátedra no se limitaba sólo a la imposición de unos determinados contenidos en la docencia. Por el contrario, y acaso como no podría ser de otro modo, aquélla se extendía también a la facultad investigadora, y al método con que está podía ejercerse. A este respecto, debemos a Pedro De Vega la observación de que, en el supuesto de la Alemania nacional-socialista, fue a Reinanhard Höhn a quien correspondió la tarea la de formular el programa al que, en sus investigaciones, deberían someterse los estudiosos de la Teoría del Estado y de la Constitución, así como, más en general, todos los que se dedicaban al Derecho del Estado (Staatsrecht). Fueron muchos los juristas y politólogos alemanes que, con independencia de sus particulares convicciones ideológicas y científicas, se plegaron a una tal imposición, y los que, por el motivo que fuese, incluido el de asegurar su propia subsistencia, aceptaron seguir, con una escrupulosa y escandalosa fidelidad, las directrices marcadas por Höhn. Ahí están, por ejemplo, los Binder, Jerusalem, Köllreuter, Krüger o Tatarin-Tamheyden.

El problema, como es obvio, se planteaba cuando algún estudioso del Estado, el Derecho o la Política no sólo no aceptaba seguir los mandatos de Höhn, sino que, además, pretendía continuar operando con la metodología de la propia. En este supuesto, la incapacidad de la dictadura para reconocer la existencia de conflictos en su seno, sería la que determinaría la solución. Elevada, de nuevo la mera discrepancia académica a la condición de auténtica discrepancia política, y con la apelación estricta de la dialéctica amigo-enemigo, los autores del positivismo jurídico podían, sin ninguna dificultad, librarse de todos aquéllos que osaban criticar su modo de hacer el Derecho Constitucional. Circunstancia ésta que es la que, en último término, explica el porqué Carl Schmitt, cuya adscripción al totalitarismo nacional-socialista era manifiesta, pudo, al no plegarse a aquel programa metodológico como universitario, tener algún problema, y recibir no pocas críticas por parte de otros juristas del régimen y por parte de sus correligionarios, una vez que Hitler llegó al poder, obligándole, sobre todo a partir de 1936, a un progresivo aislamiento en la vida académica y política.

La suerte que, en tales circunstancias, podría corresponderle a Heller no es, en nuestra opinión, difícil de imaginar. Y él, mejor que ningún otro, dada su altísima perspicacia, no podía dejar de conocerlo cuando, en marzo de 1933, sopesaba la alternativa de volver a una Alemania gobernada por el nazismo, o de partir al exilio. En todo caso, y como veremos más adelante, las peores previsiones de sus amigos y de él mismo se verían confirmadas por los hechos. 
No es, de cualquier forma, un desmedido atrevimiento afirmar que, ya en marzo de 1933, era previsible que la fortuna académica no le iba a ser favorable al más lúcido, válido y capaz de los estudiosos del Derecho, la Política y el Estado del período entre guerras. Fácil resulta pensar que Heller sólo podía ser considerado como "enemigo» y que, por ello mismo, sería objeto de persecución. En efecto, tanto los miembros de la "Escuela oficial», como, con igual certeza, quienes, universitarios o no, ocuparon los puestos directivos en el Reich no podían ignorar que no era dado imaginar que Heller, caracterizado por su espíritu crítico con la metodología empleada hasta entonces por los diversos grupos universitarios, y de una manera muy particular la con el llamado método jurídico puro, fuese a someterse voluntariamente a las exigencias académicas derivadas de la nueva realidad política. Del mismo modo, sabían que era prácticamente imposible que el autor de «Europa y el fascismo» llegase a aceptar que el contenido de sus explicaciones e investigaciones le fuere impuesto por los intereses de la clase gobernante, y mucho menos cuando se trataba de unos gobernantes a los que, desde hacía ya varios años, venía combatiendo. Tenían, por el contrario, muchos motivos para pensar que jamás se dejaría, por así decirlo, «domesticar». Lo que, de manera inevitable, habría de conducirles a la conclusión de que Heller, en la medida en que iba a poner de manifiesto un, para ellos, inaceptable conflicto interno, debía ser destruido académicamente.

\section{3.- La ideología democrático-socialista como fundamento de su consideración como «enemigo politico»}

Si, como hemos visto, su origen étnico-biológico convertía a Heller en un «enemigo personal» del Reich, y sus planteamientos científicos lo configuraban como «enemigo académico», no ha de resultar, por último, muy difícil de averiguar que algo no muy distinto sucedería en el ámbito de lo político. Y es, sin duda, esta problemática la que requiere de menores explicaciones para su ponderada y cabal comprensión.

En este sentido, señalaremos que, según nuestro parecer, el propio Heller tenía que ser bien consciente de lo que implicaba su militancia en el Partido Socialista Alemán, y, además, su adscripción al ala izquierdista o radical de aquél, cuando el nacional-socialismo, al que tanto había combatido, se convertía en la única fuerza operante en Alemania. No le podía caber la menor dudar sobre el que, situada la confrontación político-ideológica en los esquemas totalitarios, a él, convencido y activo demócrata socialista, sólo podía corresponderle la consideración de auténtico enemigo político de quienes en aquel momento ocupa- 
ban el poder en Alemania y que, con la apelación al falseamiento de la Constitución y al fraude constitucional, se esforzaban en llevar a cabo la derogación fáctica del Texto de Weimar y, con ello, la destrucción del Estado Constitucional democrático con los que en él estaba tan comprometido. De igual manera, y aunque nadie le hubiera llamado la atención al respecto, es fácil deducir que Heller hubiera llegado, en marzo de 1933, a la conclusión de que la opción por el exilio le era la más conveniente. En efecto, sabiendo, como sin duda sabía, que el Gobierno hitleriano le otorgaba la naturaleza, por decirlo en la terminología empleada por Schmitt, de hostis, y no simple innimicus, no le sería complicarlo deducir que aquél utilizaría todos los medios a su alcance para llevar a cabo su destrucción, así como el que habría no pocos juristas que se prestasen, de manera rápida y diligente, y como ha sucedido siempre en cualquier dictadura, a justificar el atropello.

Lo anterior se desprende, sin dificultad alguna, de la propia lógica de la dictadura, sobre la cual ya nos hemos pronunciado. La aplicación de aquélla lógica general al caso que ahora nos ocupa, resulta, en nuestra modesta opinión, fácilmente comprensible. Porque, como corresponde al todo régimen totalitario que, al no poder admitir la inevitable existencia de conflictos en el interior de la Comunidad Política, se ve imposibilitado para reconocer a la legitimidad de las organizaciones partidistas de la oposición a quienes, de forma sistemática, y sin excepción alguna, acusarán de ser fuerzas revolucionarias y destructoras, y que, utilizando el nacionalismo como ideología de la ocultación, hace, además, de la perfecta e inquebrantable unidad del Estado, y de la unanimidad en él, su razón de ser la última, meridiano ha de ser que el nuevo Gobierno alemán no podría tolerar la presencia, y libre actuación, de quien, como Hermann Heller, siendo judío no sólo se había mostrado, académica y políticamente, como un inquebrantable convencidos socialista defensor del sistema democrático, sino que, además, y en el ámbito de la confrontación político partidista, había adoptado, desde que, en 1920, había ingresado, de la mano de Gustav Radbruch, en el SPD, una muy activa postura la en defensa del socialismo radical, aunque no revolucionario, por un lado, y, por otro, y con idéntico ánimo e intensidad, a combatir el aparentemente irresistible avance de los totalitarismos de todo signo, y de un modo muy particular, y actuando desde la creencia de que, aunque ni la dictadura bolchevique ni la fascista puedan ser consideradas legítimas, el autentico dilema al que se enfrentaba la Europa occidental del período weimariano es el de optar «entre Dictadura fascista y Estado social de Derecho», al totalitarismo fascista. 


\section{5.- CONSIDERACIONES FINALES}

La situación del muy brillante Profesor socialdemócrata cambiaría a partir de septiembre de 1933. El exilio deja de ser para Heller una situación, de alguna manera, libremente decidida, para pasar a ser inevitable y forzosa. En efecto, sucede que lo que en marzo eran, desde el punto de vista jurídico, sólo meros temores sobre la suerte que podía correr en la Alemania nazi, se convertía, de forma definitiva y fatal, en una auténtica realidad. Ciertamente esperable y previsible. Al fin y al cabo, este cambio de naturaleza de su situación traía causa de la aprobación, el 7 de abril de 1933, de la Ley para la Reconstrucción del Funcionariado.

Norma ésta — de Derecho vigente, que en modo alguno de Derecho Positivo, sobre todo si para su enjuiciamiento acudimos al conjunto de principios y valores que el Pouvoir Constituant había consagrado en la Constitución alemana de 1919, que no había sido formalmente derogada—, que, cumpliendo con todas las exigencias y requerimientos del más estricto y ortodoxo positivismo jurídico formalista, tenía la única finalidad de otorgar la cobertura jurídica precisa al dictador para, actuando legalmente, proceder a la depuración (destrucción/aniquilación) tanto de todos los funcionarios de raza judía, como de todos los disidentes de las doctrinas nacional-socialistas que trabajaban en la Administración. De una manera especial y particularmente concreta, esta Ley se aplicó a los Profesores universitarios de tendencia democrático-progresista. Así, en efecto, fueron siendo apartados de sus puestos los Horkheimer, Kirchheimer, Neumann, Mannheim, Sinzheimer, etc.

Hermann Heller, judío y socialdemócrata, no podía escapar a su destino. Y este le alcanzó el 11 de septiembre de 1933. En esa fecha, y teniendo como fundamento el que le proporcionaba la antes citada Ley para la Reconstrucción del Funcionariado, el Gobierno hitleriano decidió su depuración. Ésta, acaso porque, al encontrarse fuera del territorio alemán, no cabía otra forma de aniquilación del enemigo político, académico y personal, se limitó al aspecto administrativo; respetándole su derecho a la vida. La sanción, en todo caso, no podía ser más dura: no sólo se le privaba de su empleo como titular de la Cátedra de Derecho Público de la Universidad de Frankfurt, a la que había accedido en marzo de 1932, sino que también se decidía su expulsión o apartamiento de toda enseñanza universitaria.

Sin duda, habría muchos de sus colegas que se alegraron y aplaudieron tal medida. Así lo harían todos aquéllos que, compitiesen con él o no, o incluso sin tener nada que ver con los problemas internos de los estudiosos del Estado, el Derecho y la Política, pertenecían a la organización partidista-estatal del nacio- 
nal-socialismo. En el mismo sentido, habría otros muchos que adoptarían una similar actitud en tanto en cuanto, aunque sin ser nazis, participaban de las tesis étnico-biológicas de la dictadura, y, en consecuencia, creían que estos criterios, ajenos a la valía intelectual y científica del afectado, debían ser los que prevalecieran en todos los órdenes de la vida, incluido el universitario. Finalmente, también habría otros que, desde la más absoluta ingenuidad, y sin darse cuenta que ellos mismos se ponían en una situación de peligro futura, no elevarían su protesta por la depuración sufrida por Heller. En muchos casos, no me cabe la menor duda, no se compartiría criterio material de la medida, pero se eludiría su enjuiciamiento porque aquélla estaba amparada por una norma jurídica aprobada, con su correspondiente nomem iuris, por el órgano legal-constitucionalmente facultado para ello y con una escrupulosa observancia del procedimiento previamente establecido al efecto.

El exilio, en una y otra manifestación, lo viviría, casi en su totalidad, Heller ejerciendo como docente e investigador en la Segunda República española. No podemos, como es obvio, detenernos aquí a realizar un estudio exhaustivo y pormenorizado de cuáles fueron las causas reales que le condujeron a elegir este destino. Esto sería, sin duda, algo muy interesante de hacer, y prometo abordarlo en alguna otra ocasión. De cualquier modo, diré que, a mi juicio, su decisión no puede entenderse como casual, sino perfectamente lógica y coherente con el carácter de quien, como nos dice el Maestro Mario de la Cueva, se presenta, desde una óptica doctrinal y política, como el gran «paladín de la soberanía y de las libertades de los pueblos débiles».

A la Segunda República española llegó en la primavera de 1933. Y lo hizo al aceptar — rechazando la posibilidad de incorporarse a la New School for Social Sciences de Nueva York- la invitación que, a instancias de Antonio de Luna, Catedrático de Derecho Internacional Público de la Universidad Central de Madrid (actual Universidad Complutense), le cursó el entonces Ministro de Instrucción Pública, el socialista, y también Catedrático de Derecho Político, D. Fernando de los Ríos.

Nombrado por la Orden Ministerial de 16 de mayo de 1933, quien había ejercido como docente e investigador en las Universidades de Kiel, Lipsia, Berlín y Frankfurt se incorporaría al Instituto de Estudios Internacionales y Económicos como Profesor Extraordinario. En este centro, el constitucionalista y politólogo alemán se haría cargo de las explicaciones de las materias de Sociología y Ciencia Política. De manera más o menos simultánea, Heller quedaría adscrito, también como Profesor Extraordinario, a la Cátedra de Derecho Político de la Universidad Central, de la que era titular Pérez Serrano, y en la que Francisco Ayala ejercía como auxiliar. En este último empleo, nuestro autor co- 
menzaría, en octubre de 1933, a impartir un curso en la Facultad de Derecho, que era, justamente, el que estaba impartiendo cuando sufrió el ataque al corazón que le causó la muerte.

Esto sucedió el 5 de noviembre de 1933. Con su muerte, la Universidad, como ente universal sin límites geográficos o administrativos, perdía uno de sus más valiosos trabajadores. Los universitarios, los de entonces y los de ahora, perderíamos un modelo de seriedad, rigor, y coherencia no sólo no académico, sino también en lo personal y en lo político.

Si Heller moría el 5 de noviembre, la Segunda República, si hemos de creer a Antonio Machado, comenzaría su letal y progresiva agonía poco después: el 19 de noviembre de 1933. Ésta se iniciaría con el triunfo electoral de quienes, habiendo contribuido a hacer de España una República republicana, y llevados por un insano principio del honor monárquico que se había manifestado en la recuperación de las viejas técnicas de la Restauración, se mostraron dispuestos a entregar el poder a las fuerzas políticas no republicanas. La, en términos taurinos, "puntilla» llegaría cuando estas mismas fuerzas que se habían visto favorecidas por la política, primero contrarrevolucionaria, y posteriormente claramente reaccionaria, de Lerroux y Alcalá-Zamora, procedieron, bajo la rara especie de que iban a reconstruir el Imperio español, a invitar a que conquistaran España a aquéllos de los que había tenido que huir Heller. La muerte definitiva llegaría el 1 de abril de 1939. Y con ella, y en tanto en cuanto la Segunda República representaba el último intento de poner en marcha un sistema de libertad total en la vieja Europa, lo haría la Humanidad toda, pues, como había proclamado Azaña, «La libertad no hace felices a los hombres; los hace simplemente hombres».

Title:

HERMANN HELLER GOES TO THE EXILE: A ESSAY OF THEORY OF THE POLITICAL AND CONSTITUTIONAL THOUGHT

\section{Summary}

I. MEANING AND SIGNIFICANCE OF THIS WRITING. THE TRIBUTE AS JUSTICE AND MORAL REPARATION TO MANUEL GARCÍA-PELAYO. II. MARCH 1933, A DATE KEY IN THE LIFE OF HERMANN HELLER: GOES IT INTO EXILE. III. OBJECTIVE THEORIC-IDEOLOGIC CONSIDERATIONS 
THAT JUSTIFIED THE HELLER'S DECISION TO NOT RETURNING TO GERMANY. IV. PERSONAL PREDICTABLE SITUATION IN THE DICTATORSHIP AS CAUSE OF EXILE: HELLER AS «TOTAL ENEMY». V. FINAL CONSIDERATIONS.

\section{Resumen:}

Este trabajo, escrito en honor de García Pelayo, trata de poner de manifiesto los motivos que condujeron a Hermann Heller a no volver a la República alemana, haciéndolo desde la perspectiva del pensamiento político-constitucional. Estos motivos pueden ser encuadrados en dos grandes bloques. El primero, de carácter objetivo, se concreta en la destrucción del régimen constitucional y del sistema democrático-parlamentario, creado por el texto de 1919 que habría de producirse con el acceso del nazismo al poder. El segundo haría referencia a la situación personal de Heller en el marco de la dictadura Hitleriana, y que puede definirse como la de «enemigo total» del régimen.

\section{Palabras Clave:}

Constitución, Estado, Democracia, Dictadura, Nacionalismo etnicista.

\section{Abstract:}

This essay, written like an homage to García Pelayo, tries to make clear the reasons that led Hermann Heller not to return to the German Republic. We made it from the political-constitutional theory point of view. These reasons can be framed in two main blocks. The first one, with an objective nature, is the destruction by the Nazism in the government of the constitutional regime, and of democratic-parliamentary system, created by the Text of 1919. The second one, refers to Heller's personal position in the political context of hitlerian dictatorship, and can be established as «total enemy» of the regime.

\section{Key words:}

Constitution, State, Democracy, Dictatorship, Ethnic Nationalism. 